Review

\title{
Zebrafish as a Model for Developmental Neurotoxicity Assessment: The Application of the Zebrafish in Defining the Effects of Arsenic, Methylmercury, or Lead on Early Neurodevelopment
}

\author{
Jinyoung Lee and Jennifer L. Freeman *
}

School of Health Sciences, Purdue University, 550 Stadium Mall Drive, West Lafayette, IN 47907, USA; E-Mail: lee1398@purdue.edu

* Author to whom correspondence should be addressed; E-Mail: jfreema@purdue.edu; Tel.: +1-765-494-1408; Fax: +1-765-496-1377.

Received: 15 May 2014; in revised form: 22 August 2014 / Accepted: 25 August 2014 /

Published: 10 September 2014

\begin{abstract}
Developmental exposure to neurotoxic chemicals presents significant health concerns because of the vulnerability of the developing central nervous system (CNS) and the immature brain barrier. To date, a short list of chemicals including some metals have been identified as known developmental neurotoxicants; however, there are still numerous chemicals that remain to be evaluated for their potential developmental neurotoxicity (DNT). To facilitate evaluation of chemicals for DNT, the zebrafish vertebrate model system has emerged as a promising tool. The zebrafish possesses a number of strengths as a test species in DNT studies including an abundance of embryos developing ex utero presenting ease in chemical dosing and microscopic assessment at all early developmental stages. Additionally, rapid neurodevelopment via conserved molecular pathways supports the likelihood of recapitulating neurotoxic effects observed in other vertebrates. In this review, we describe the biological relevance of zebrafish as a complementary model for assessment of DNT. We then focus on a metalloid and two metals that are known developmental neurotoxicants (arsenic, methylmercury, and lead). We summarize studies in humans and traditional vertebrate models and then detail studies defining the toxicity of these substances using the zebrafish to support application of this model system in DNT studies.
\end{abstract}

Keywords: arsenic; development; DNT; lead; metalloids, metals; methylmercury; neurotoxicity; zebrafish 


\section{Introduction}

Developmental exposure to certain chemicals are suggested as possible causes of neurodevelopmental impairments including reduced intelligence quotient (IQ), autism spectrum disorder (ASD) and attention deficit hyperactivity disorder (ADHD) [1-4]. The particular susceptibility of the developing central nervous system (CNS) has been noted for decades and several publications suggest that there might be a critical window of exposure during brain development [5-8]. It has also been discussed that early-life stimulation via environmental stressors such as chemical exposures may trigger genetic or epigenetic changes that modulate an organism's biological system, which in turn leads to neurodevelopmental alterations [7,9-11]. Thus, exposure of early-life organisms to certain chemical compounds, especially during the critical period of development including prenatal and early postnatal stages, can have significant adverse impacts on the process of CNS development. In addition, some characteristics of neurodevelopmental disorders (e.g., those associated with ADHD and ASD) can continue into adulthood, implying the adverse effects of a childhood neurodevelopmental alteration can influence health throughout the lifespan $[12,13]$.

To date, several chemicals including some metals and their related compounds are noted as neurotoxicants (reviewed in [14,15]). However, currently there is insufficient evidence to prove developmental neurotoxicity (DNT) for the majority of chemicals with only a few of them (e.g., arsenic, methylmercury, and lead) reported as known developmental neurotoxicants (reviewed in $[14,15])$. Environmental contamination of arsenic, methylmercury, and lead is widespread, resulting in frequent human exposure raising public health concerns (reviewed in [16-20]). These toxicants are non-biometals that do not play a role in biological systems and have been associated with neurodevelopmental alterations in developing organisms [3,21-23].

The little progress in identifying the DNT of chemicals is in part due to the limitation of studies using conventional in vivo models (e.g., non-human primates and rodent models), of which experiments are laborious, time-consuming, and may not be cost-effective. To this end, the zebrafish model system has emerged as a suitable complementary in vivo DNT test model. This model system has been applied historically as a powerful in vivo tool for developmental biology studies with numerous strengths as a laboratory test animal. The embryonic developmental stages of zebrafish are well documented, which provides a guide for researchers to identify major physiological alterations occurring during developmental toxicity assays [24]. Moreover, there is continuous progress on uncovering the developmental processes of the CNS and blood-brain-barrier (BBB) of the zebrafish [25-30]. Overall development of the zebrafish CNS and patterning of brain sub-regions are completed within three days after fertilization during which neurogenesis and formation of pioneer axons initiate (Figure 1). The rapid CNS development coupled with the general strengths of the zebrafish model system allows screening of chemical compounds for potential DNT, resulting in the zebrafish being an ideal complementary model for DNT studies.

In this review, the general merits and biological significance of the zebrafish as a DNT test model are described. We then summarize DNT studies of a known metalloid and two metal neurotoxicants (i.e., arsenic, methylmercury, and lead) in humans and traditional vertebrate models. Moreover, we introduce research studies utilizing the zebrafish for DNT assessment of various chemicals and also show potential of the zebrafish as an in vivo model for rapid chemical-induced DNT screening. Finally, 
we discuss progresses made in studies on the DNT of arsenic, methylmercury, and lead using the zebrafish to support the application of this model system in DNT studies.

Figure 1. Zebrafish neurodevelopment. (a) At $72 \mathrm{~h}$ post fertilization (hpf) major subdivisions of the zebrafish brain are present; Zebrafish axonal networks visualized by acetylated $\alpha$-tubulin staining (b) at $72 \mathrm{hpf}$, (c) at $96 \mathrm{hpf}$, and (d) at $120 \mathrm{hpf}$ of development. Scale bar $=100 \mu \mathrm{m}$. (C, cerebellum; H, hindbrain; M, midbrain; F, forebrain).

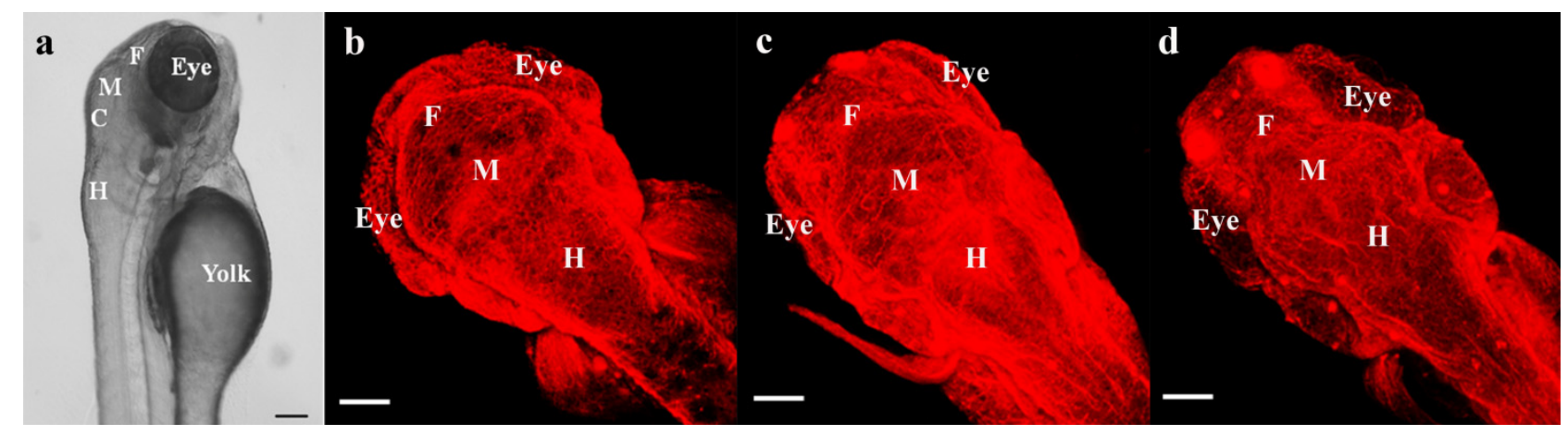

\section{Zebrafish as a Model for DNT}

\subsection{General Strengths of the Developmental Zebrafish Model System}

The zebrafish model system has long been applied in the field of developmental biology [31-35]. Over the past decade, the zebrafish has also emerged as a popular tool for investigating the neurotoxicity of drugs and environmental chemicals [36-66]. The zebrafish presents numerous strengths as an in vivo test model including ex utero fertilization and transparency of embryos and early larvae, enabling microscopic observation through early developmental stages. The ex utero embryonic development also eases the determination of doses of exposed chemicals at all embryonic stages, providing explanation of exposure kinetics of chemicals of interest [67-70]. Moreover, the rapid growth and high fecundity of zebrafish facilitate higher throughput toxicity testing of multiple chemicals. In addition, a high degree of genetic similarity $(\approx 70 \%)$ with humans allows application of zebrafish for human disease genetic studies [71]. The fully sequenced zebrafish reference genome, combined with the ability to use reverse genetic approaches, eases mechanistic studies on chemical toxicity using this species. The similarity of neural development between the zebrafish and other vertebrates also supports the application of the zebrafish as a complementary research tool to conventional vertebrate models for DNT assays [25,28,72]. There is also biological similarity between the zebrafish and other vertebrates in the development and function of biological barrier systems in the developing CNS (i.e., the BBB). The BBB is one of the most effective barrier systems in vertebrates and it is generally accepted that the BBB plays a pivotal role in the protection of the brain against neurotoxic insults. While there are many similarities, there are also some differences between the development of the zebrafish and mammalian brain. These similarities and differences are discussed below. 


\subsection{Comparison of Mammalian and Zebrafish CNS Development}

Following fertilization in vertebrates, the newly formed embryo undergoes several cycles of rapid cell division, during which a blastula (i.e., a single-cell organism) transforms into an embryo at the gastrula stage (i.e., a multi-cell organism). During gastrulation, three germ layers including the endoderm (the interior germinal layer), ectoderm (the outside germinal layer), and mesoderm are formed. The ectoderm, specifically the neuroectoderm, gives rise to the CNS (reviewed in [25,28]), whereas the endoderm and mesoderm are involved in the development of other organs (e.g., the kidney, liver, and pancreas) and tissues (e.g., bone and connective tissue). The neuroectoderm specifies to the neural plate, the origin of the CNS. The formation of the neural plate is followed by the neurulation process, in which the neural plate folds to generate the neural tube (reviewed in [25,28]). The neural tube eventually forms major components of the CNS including the brain, spinal cord, and nerves. Similar to the general processes of vertebrate neurogenesis, development of the zebrafish CNS also begins with the specification of the neuroectoderm and generation of the neural plate. At this point, the zebrafish embryo undergoes a slightly different process from general vertebrate neurulation. Unlike most vertebrates, which directly generate the neural tube by neural plate folding, the zebrafish converts the neural plate to the neural keel, which then forms the neural rod and then the neural tube $[28,73]$.

The arrangement of critical divisions of the brain proceeds during gastrulation. In the zebrafish, gastrulation occurs from 5.25-6 to $10 \mathrm{~h}$ post fertilization (hpf), during which precursors of the forebrain and other regions (i.e., the midbrain, hindbrain, and spinal cord) proceed toward the anterior and more posterior positions, respectively [24,30]. Zebrafish primary neurons appear by $24 \mathrm{hpf}$, forming simple neuronal clusters in neuromeres (reviewed in [74]). During early embryogenesis, there are only a few axonal tracts and commissures, but with the initiation of axonal projections by the primary neurons complex neuro-networks throughout the body through later developmental stages are gained (Figure 1b-d) [74-78]. The morphological development of major organ systems nears completion at the end of embryogenesis $(\approx 72 \mathrm{hpf})$ with the BBB present at an earlier stage [24,29].

\subsection{Blood-Brain Barrier (BBB) in the Zebrafish}

The BBB is composed of endothelial cells on cerebral blood capillaries. The BBB protects the brain from toxicants by preventing free-transport of substances. The filtering function of the BBB occurs by endothelial cells connected through tight junctions restricting free movement of ions or solutes (e.g., toxicants and macromolecules) between inside and outside of the barrier (reviewed in [79]). The $\mathrm{BBB}$ also isolates neurotransmitters and neuroactive substances in the CNS from those in the peripheral nervous system, hindering the interaction between the two systems (reviewed in [79-81]). Most water soluble substances are not able to freely enter the BBB because the tight junctions that connect nearby endothelial cells limit the movement of hydrophilic solutes through paracellular networks [79,82]. However, substances with low molecular weight or lipophilic characteristics can diffuse through the transmembrane relatively easy, implying that the BBB is not an absolute barrier against neurotoxic chemicals $[83,84]$. 
Although the BBB may play a significant role in understanding the influence of exposure to neurotoxic substances on the developing brain, the functional mechanism and the maturation process still remain to be elucidated. It has been a generally accepted notion that the formation of the BBB is not complete during early developmental stages; in humans, it is not until the age of 6 months, during which the young brain still undergoes critical development up until 2 years of age [85-87]. However, this assumption of the immature $\mathrm{BBB}$ has been challenged with increasing evidence showing that the BBB appears at very early developmental stages and that proteins involved in BBB formation and also functional tight junctions exist in the developing brain (reviewed in [88-90]). There are several important players involved in the BBB junctional complex activity that maintains the homeostasis of the brain including two tight junction proteins: Claudin-5 and Zona occludens protein 1 (ZO-1) [91-96]. The genes encoding these proteins in humans (CLDN5 and TJP1, respectively) and in mice (Cldn5 and Tjp1, respectively) are also found in zebrafish as $c l d n 5 a$ and $c l d n 5 b$, and as tjpla and tjplb [97-101].

The presence of the BBB in zebrafish at early life stages became evident by Umans and Taylor [29] when a drug transporter protein (i.e., multidrug resistance protein 1) at the BBB was immunohistochemically visualized at $48 \mathrm{hpf}$. While the exact timing of complete maturation of zebrafish BBB is unclear, it has been revealed that two tight junction proteins, Claudin-5 and ZO-1, in zebrafish brain endothelial cells are expressed as early as 72 hpf [27]. As visualized by Jeong et al. [27], the BBB of zebrafish is functional at $72 \mathrm{hpf}$ as the leakage of an injected large molecular weight tracer, rhodamine-dextran $(10 \mathrm{kDa})$ was restricted in microvessels of brain parenchyma. The zebrafish BBB may undergo further maturation to exclude small molecules after completion of embryogenesis, as shown in Fleming et al. [102] with the inclusion of Evans blue (961 Da) and sodium fluorescein (376 Da), restricted through 5 and 10 days after fertilization, respectively.

Due to the vulnerability of the developing CNS and limited information about the BBB function of organisms at early life stages, a developmental exposure to environmental chemicals raises significant concerns for potential detrimental effects to the CNS and contribution to neurodevelopmental disorders. To date, a short list of chemicals including some metals and metalloids (e.g., arsenic, methylmercury, and lead) are identified as known developmental neurotoxicants (reviewed in $[14,15]$ ). In the sections below, we summarize the developmental neurotoxic effects of these toxicants as observed in humans and in traditional in vivo vertebrate animal models. We also introduce studies on various chemicals subjected to DNT testing using the zebrafish model. We then detail studies that have used the zebrafish model system for DNT assessment of arsenic, methylmercury, and lead.

\section{DNT of Arsenic, Methylmercury, and Lead}

\subsection{Arsenic}

Arsenic is a metalloid element existing in nature, which can be found in an inorganic or organic form with several oxidation states, including trivalent arsenic (arsenite) and pentavalent arsenic (arsenate). Exposure to arsenic raises health concerns as it can damage our body by interacting with biomolecules and produce reactive oxygen species (reviewed in [103]). Arsenic has a long history of use as a pesticide, food preservative, and cancer chemotherapeutic agent (reviewed in [103]). Although the application of arsenic in the production of pesticides and food preservatives has mostly 
been phased out, human exposure to arsenic still occurs because of the widespread environmental contamination and natural presence in geological stores in some regions of the globe [18,19,104-108].

Epidemiological studies report a number of arsenic exposure cases through contaminated drinking water supplies. Global epidemiological studies report a close relationship between early-life arsenic exposure and intellectual/cognitive ability of school-aged children [109-112]. For example, in a recent study conducted in the United States (US), Wasserman et al. [112] investigated the association of arsenic exposure through drinking water at home and the IQ levels of 272 school-aged children (mean age of 9.67-years) with the mean residence time in the current dwelling place ( 7.34 years). Researchers compared the IQ of children exposed to low levels of arsenic (arsenic concentrations in water below $5 \mu \mathrm{g} / \mathrm{L}$ ) to the IQ scores of those exposed to high levels of arsenic (arsenic concentrations in water between 5-10 $\mu \mathrm{g} / \mathrm{L}$ ). In participants exposed to high levels of arsenic, there was a significant decrease in the overall intellectual ability with about a six-point decrement in full scale IQ [112].

When tested with younger aged groups, however, the adverse effects of arsenic exposure on children's intellectual development becomes inconclusive [109,113]. For example, Nahar et al. [109] and Hamadani et al. [113] examined the association of children's IQ levels with urinary arsenic concentrations obtained from the participants at the age of 4 and/or 5 years. In the study of Nahar et al. [109], researchers found an association between arsenic concentration in urine and a significant decrease in non-verbal IQ levels, but not in verbal IQ. On the other hand, Hamadani et al. [113] found a significant negative relationship between the urinary arsenic levels and verbal as well as full scale IQ of female children at 5 years of age.

There are also studies completed on infantile neurodevelopment in relation to prenatal arsenic exposure. According to two recent birth cohort studies, the impact of arsenic exposure on early neurodevelopment may not be identical in infants at different ages [114,115]. When a study was conducted with 1-day old infants, researchers did find a negative relationship between the arsenic levels measured in cord blood and the neurodevelopmental status of newborns when evaluated by Brazelton Neonatal Behavioral Assessment Scale (III) [115]. However, this negative relationship did not appear in a more recent study with neurodevelopment evaluated by the Bayley Scale of Infant Development (II) using a cohort of 6-month old infants [114].

Rodent studies have reported reproducible results showing neurobehavioral and neurophysiological alterations following a developmental arsenic exposure continuing over different periods of time [116-118]. In studies conducted under sub-chronic or chronic exposure conditions, rats treated with arsenite from early gestation exhibited behavioral changes with impaired learning/memory ability [117,118]. For instance, rats treated with $36.7 \mathrm{mg} / \mathrm{L}$ arsenite from gestation day (GD) 15 through 4 months of age exhibited significant alterations in spontaneous locomotion and poor performance in the delayed alternation test [117]. In addition, more recent studies with shorter exposure periods (e.g., arsenite exposure beginning in early gestation until weaning) show molecular-level changes occurring in the rat brain, including reduced enzymatic antioxidant activity and altered expression of neural cell adhesion molecules [116,119]. Studies conducted in the past five years on the neurotoxic effects of arsenic exposure with rodent models in developmental stages are summarized in Table 1. 
Table 1. A selection of studies carried out over the past five years on the neurotoxic effects of arsenic, $\mathrm{MeHg}$, or $\mathrm{Pb}$ exposure in the zebrafish or in vivo rodent models during developmental stages.

\begin{tabular}{|c|c|c|c|c|c|c|}
\hline Substance & Endpoints & In Vivo Model & Concentration $^{\mathrm{a}}$ & Exposure Period $^{\text {b }}$ & Key Observations $^{\text {c }}$ & References \\
\hline \multirow{4}{*}{ Arsenic } & $\begin{array}{l}\text { Axonal/nerve } \\
\text { growth }\end{array}$ & Zebrafish & $2 \mathrm{mM}$ & 4-48 hpf & $\begin{array}{l}\text { Altered axon outgrowth in the brain and nerve growth in } \\
\text { the spinal cord }\end{array}$ & $\begin{array}{l}\text { Li et al. } \\
{[120]}\end{array}$ \\
\hline & \multirow{3}{*}{$\begin{array}{l}\text { Behavioral } \\
\text { alteration }\end{array}$} & \multirow[b]{2}{*}{ Rat } & $\begin{array}{l}13.6 \mathrm{mg} / \mathrm{L} \\
(\approx 0.1 \mathrm{mM})\end{array}$ & GD0-PND21 & Delayed behavioral development (reflex responses) & $\begin{array}{l}\text { Luo et al. } \\
{[116]}\end{array}$ \\
\hline & & & $\begin{array}{l}10 \mathrm{mg} / \mathrm{L} \\
(\approx 0.08 \mathrm{mM}) \\
\text { or above }\end{array}$ & GD6-PND42 & Altered reflex responses or learning/memory behaviors & $\begin{array}{l}\text { Xi et al. } \\
{[118]}\end{array}$ \\
\hline & & Zebrafish & $\begin{array}{l}2 \mathrm{mM} \\
\text { or above }\end{array}$ & $4-30 \mathrm{hpf}$ & $\begin{array}{l}\text { Decrease in reflexive movement frequency under } \\
\text { light stimulation }\end{array}$ & $\begin{array}{l}\text { Li et al. } \\
{[120]}\end{array}$ \\
\hline \multirow{6}{*}{$\mathrm{MeHg}$} & \multirow{5}{*}{$\begin{array}{l}\text { Transcriptomic } \\
\text { endpoint }\end{array}$} & Rat & $\begin{array}{l}0.1 \mathrm{mg} / \mathrm{kg} \\
(\approx 0.5 \mu \mathrm{M}) \\
\text { or above }\end{array}$ & GD6-PND10 & $\begin{array}{l}\text { Altered expression of genes related to brain } \\
\text { development functional cluster in female offspring brain }\end{array}$ & $\begin{array}{l}\text { Radonjic } \\
\text { et al. }[121]\end{array}$ \\
\hline & & \multirow{3}{*}{ Mouse } & $\begin{array}{l}4 \mathrm{mg} / \mathrm{kg} \\
(\approx 0.02 \mathrm{mM})\end{array}$ & $\begin{array}{l}\text { for } 9 \text { weeks including } \\
\text { gestation period and } \\
2 \text { weeks post-partum }\end{array}$ & $\begin{array}{l}\text { Altered expression of genes related to functional classes } \\
\text { of cell morphology/function, growth factor activity, or } \\
\text { receptor binding in pup brain }\end{array}$ & $\begin{array}{l}\text { Jayashankar } \\
\text { et al. }[122]\end{array}$ \\
\hline & & & $\begin{array}{l}2.6 \mathrm{mg} / \mathrm{kg} \\
(\approx 0.01 \mathrm{mM})\end{array}$ & $\begin{array}{l}\text { for } 8 \text { weeks including } \\
\text { gestation period and } \\
2 \text { weeks post-partum }\end{array}$ & $\begin{array}{l}\text { Altered expression of genes enriched in cell proliferation } \\
\text { or stress response functions in pup brain }\end{array}$ & $\begin{array}{l}\text { Jayashankar } \\
\text { et al. }[123]\end{array}$ \\
\hline & & & $\begin{array}{l}1.5 \mathrm{mg} / \mathrm{kg} \\
(\approx 0.007 \mathrm{mM}) \\
\text { or above }\end{array}$ & $\begin{array}{l}\text { for } 11 \text { weeks including } \\
\text { gestation period and } \\
2 \text { weeks post-partum }\end{array}$ & $\begin{array}{l}\text { Exposure to } \mathrm{MeHg} \text { chloride or } \mathrm{MeHg} \text { cysteine altered } \\
\text { expression of genes involved in functional clusters of } \\
\text { immunoglobulin, metal/zinc binding, or methylation in } \\
\text { pup brain }\end{array}$ & $\begin{array}{l}\text { Glover et al } \\
{[124]}\end{array}$ \\
\hline & & Zebrafish & $\begin{array}{l}60 \mu \mathrm{g} / \mathrm{L} \\
(\approx 0.3 \mu \mathrm{M})\end{array}$ & $48-72 \mathrm{hpf}$ & $\begin{array}{l}\text { Altered expression of clusters of genes involved in } \\
\text { apoptosis, oxidative stress response, transcriptional } \\
\text { elongation, or DNA repair }\end{array}$ & $\begin{array}{l}\text { Ho et al. } \\
{[125]}\end{array}$ \\
\hline & $\begin{array}{l}\text { Behavioral } \\
\text { alteration }\end{array}$ & Rat & $\begin{array}{l}0.5 \mathrm{mg} / \mathrm{kg} \\
(\approx 0.002 \mathrm{mM})\end{array}$ & GD7-PND21 & $\begin{array}{l}\text { Altered vertical activity in 2-month old female, but not } \\
\text { in male rats }\end{array}$ & $\begin{array}{l}\text { Cauli et al. } \\
{[126]}\end{array}$ \\
\hline
\end{tabular}


Table 1. Cont.

\begin{tabular}{|c|c|c|c|c|c|c|}
\hline Substance & Endpoints & In Vivo Model & Concentration $^{\mathrm{a}}$ & Exposure Period $^{\text {b }}$ & Key Observations $^{\text {c }}$ & References \\
\hline & & Mouse & $\begin{array}{l}1.5 \mathrm{mg} / \mathrm{kg} \\
(\approx 0.007 \mathrm{mM})\end{array}$ & $\begin{array}{l}\text { for } 11 \text { weeks including } \\
\text { gestation period and } \\
2 \text { weeks post-partum }\end{array}$ & $\begin{array}{l}\text { Altered open field activity in pups exposed to } \mathrm{MeHg} \\
\text { chloride, but not } \mathrm{MeHg} \text { cysteine }\end{array}$ & $\begin{array}{l}\text { Glover et al. } \\
{[124]}\end{array}$ \\
\hline \multirow{10}{*}{$\mathrm{Pb}$} & \multirow{2}{*}{$\begin{array}{l}\text { Transcriptomic } \\
\text { endpoint }\end{array}$} & Mouse & $0.1 \mathrm{mM}$ & GD8-PND21 & $\begin{array}{l}\text { Altered expression of genes related to signal } \\
\text { transduction pathway in female pup brain }\end{array}$ & $\begin{array}{l}\text { Kasten-Jolly } \\
\text { et al. }[127]\end{array}$ \\
\hline & & Zebrafish & $\begin{array}{l}100 \mathrm{ppb} \\
(\approx 0.5 \mu \mathrm{M})\end{array}$ & $\begin{array}{l}2-16 \text { cell stage } \\
-72 \mathrm{hpf}\end{array}$ & $\begin{array}{l}\text { Altered global expression of genes related to } \\
\text { neurological development, functioning, or diseases }\end{array}$ & $\begin{array}{l}\text { Peterson } \\
\text { et al. }[128]\end{array}$ \\
\hline & $\begin{array}{l}\text { Axonal/nerve } \\
\text { growth }\end{array}$ & Zebrafish & $\begin{array}{l}100 \mathrm{ppb} \\
(\approx 0.5 \mu \mathrm{M})\end{array}$ & $\approx 2-\approx 36 \mathrm{hpf}$ & Decreased density of axon tracts & $\begin{array}{l}\text { Zhang et al. } \\
{[70]}\end{array}$ \\
\hline & \multirow{7}{*}{$\begin{array}{l}\text { Behavioral } \\
\text { alteration }\end{array}$} & \multirow{2}{*}{ Rat } & $\begin{array}{l}5 \mathrm{mg} / \mathrm{L} \\
(\approx 0.02 \mathrm{mM})\end{array}$ & $\begin{array}{l}\text { GD0-60 days of age } \\
\text { in offspring }\end{array}$ & Increased locomotor activity & $\begin{array}{l}\text { Luo et al. } \\
{[129]}\end{array}$ \\
\hline & & & $\begin{array}{l}2.84 \mathrm{mg} / \mathrm{mL} \\
(\approx 14 \mathrm{mM})\end{array}$ & GD1-PND24 & $\begin{array}{l}\text { Maternal } \mathrm{Pb} \text { exposure did not induce anxiety-related } \\
\text { behavioral change in pups }\end{array}$ & $\begin{array}{l}\text { Molina et al. } \\
{[130]}\end{array}$ \\
\hline & & \multirow{5}{*}{ Zebrafish } & $\begin{array}{l}10 \mathrm{nM} \\
\text { or above }\end{array}$ & $<2-24 \mathrm{hpf}$ & $\begin{array}{l}\text { Altered startling behavior in response to tapping } \\
\text { stimulation }\end{array}$ & $\begin{array}{l}\text { Rice et al. } \\
{[131]}\end{array}$ \\
\hline & & & $\begin{array}{l}0.1 \mathrm{mg} / \mathrm{L} \\
(\approx 0.5 \mu \mathrm{M}) \\
\text { or above }\end{array}$ & $\approx 6-8$ to $20-30 \mathrm{hpf}$ & Altered spontaneous movement & \multirow{3}{*}{$\begin{array}{l}\text { Chen et al. } \\
{[132]}\end{array}$} \\
\hline & & & \multirow{2}{*}{$\begin{array}{l}0.025 \mathrm{mg} / \mathrm{L} \\
(\approx 0.1 \mu \mathrm{M}) \\
\text { or above }\end{array}$} & 6-96 hpf & $\begin{array}{l}\text { Altered swimming activity in response to } \\
\text { light stimulation }\end{array}$ & \\
\hline & & & & $6-120 \mathrm{hpf}$ & Altered swimming activity under light or dark condition & \\
\hline & & & $0.2 \mathrm{mM}$ & $0-144 \mathrm{hpf}$ & Altered spontaneous swimming activity & $\begin{array}{l}\text { Dou and } \\
\text { Zhang [133] }\end{array}$ \\
\hline
\end{tabular}

${ }^{a}$ Concentration of substances tested on animals followed by key observation; ${ }^{\mathrm{b}}$ GD, gestational day; hpf, hours post fertilization; PND, post-natal day; ${ }^{\mathrm{c}}$ Significance of key observations is described in comparison to that of control. 


\subsection{Methylmercury}

Mercury $(\mathrm{Hg})$ is a common metal that is naturally present in the environment. $\mathrm{Hg}$ can also be released by human activities such as gold mining or coal burning, which in turn contaminates air, soil, and water [134]. In the aquatic environment, $\mathrm{Hg}$ accumulates in aquatic biota and biomagnifies through the food chain. As a result, animals at the top of the food web (e.g., heavy seafood consumers) tend to be exposed to relatively high levels of $\mathrm{Hg}$. Similarly, seafood consumption has also been pointed out as a primary source of human exposure to $\mathrm{Hg}[135,136]$. $\mathrm{Hg}$ can exist in several oxidation states including elemental $\left(\mathrm{Hg}^{0}\right)$, mercurous $\left(\mathrm{Hg}^{1+}\right)$, and mercuric mercury $\left(\mathrm{Hg}^{2+}\right)$. The mercurous and mercuric $\mathrm{Hg}$ can interact with carbon containing compounds, resulting in the formation of methylmercury $(\mathrm{MeHg})$ and ethylmercury.

Historically, health concerns of CNS exposure to $\mathrm{Hg}$ have mainly arisen from exposure to $\mathrm{MeHg}$ (reviewed in $[137,138]$ ). Therefore, the emphasis in much research has been placed on revealing the neurotoxicity of $\mathrm{MeHg}$, especially in prenatal and early postnatal organisms. The potent neurotoxic effect of $\mathrm{MeHg}$ during development is well known from the environmental disaster in Minamata, Japan in the mid-1950s. In this early event, maternal consumption of seafood contaminated with high levels of $\mathrm{MeHg}$ (i.e., umbilical cord blood level at $1 \mathrm{ppm}$ or higher) resulted in the poisoning of the fetus (reviewed in [138]). Consequently, the affected infants diagnosed with congenital Minamata disease exhibited a variety of neurodevelopmental symptoms (e.g., mental retardation, dysarthria, and chorea) with severe damage in the brain cortex and cerebellum (reviewed in [138]).

In later years, two important cohort studies, the Seychelles Child Development Study (SCDS) and a study with the Faroese birth cohort, were conducted to examine the effect of prenatal MeHg exposure on the neurodevelopment of children. Both of these studies recruited cohorts of offspring who were maternally exposed to $\mathrm{MeHg}$ through high-fish diets, but showed dissimilar results. One prospective study using the Seychelles cohort started with hair sampling of 779 pregnant women for $\mathrm{MeHg}$ measurements in 1989-1990 [139]. The measured hair MeHg level, an indicator of maternal $\mathrm{MeHg}$ exposure, was used for comparison with the offspring's neurodevelopmental status evaluated by applying age appropriate test batteries (e.g., the Bayley Scales of Infant Development and Wechsler Intelligence Scale for Children) at 6, 19, 29, 66 and 107 months of age [139]. There are a number of publications using the cohort of the SCDS that have followed up on the neurodevelopmental status of the test participants (up to 17 years of age in Davidson et al. [140]); however, the clear association between maternal $\mathrm{MeHg}$ exposure and neurodevelopmental alterations in the affected offspring has not been identified [140-143].

Another study was performed with a birth cohort in the Faroe Islands that included 1022 children born during 1986-1987 [144-147]. In studies using this birth cohort, researchers measured $\mathrm{MeHg}$ levels in maternal hair and cord blood to estimate the level of prenatal exposure. Offspring were then subjected to neurobehavioral tests (e.g., the Boston Naming Test and the California Verbal Learning Test) at 7 and 14 years of age [144-147]. Unlike the results shown in the SCDS, children in the Faroese Islands exposed to $\mathrm{MeHg}$ as a fetus exhibited neurobehavioral alterations, suggesting the negative impact of prenatal MeHg exposure on the offspring's neurodevelopment [144-147].

There are also studies reporting new observations that prenatal $\mathrm{MeHg}$ exposure may cause damage in brain areas involved in the processing of visual information [148,149]. For example, when 102 Inuit 
children were tested at preschool age, higher plasma $\mathrm{MeHg}$ levels in children were associated with altered ability of brain visual processing [148]. Similar neuropsychological alterations were also reported in teenagers (14 years of age), suggesting that maternal $\mathrm{MeHg}$ exposure may have a long lasting impact on offspring's visual information processing capability [149].

In addition, nonhuman primate studies have been conducted on the DNT of $\mathrm{MeHg}$ [150]. Gunderson et al. [151,152] reported that maternal MeHg exposure of non-human primates impaired the cognitive ability of their offspring, leading to decreased visual recognition memory in affected infants. In Burbacher et al. [153], infant monkeys maternally exposed to $\mathrm{MeHg}$ exhibited altered social behavior compared to the control monkey offspring. Long-term postnatal exposure to $\mathrm{MeHg}$ also negatively impacted visual function in monkeys at older ages $(\approx 4$ years of age) $[154,155]$.

In vivo rodent models developmentally exposed to $\mathrm{MeHg}$ exhibited neurobehavioral (e.g., motor activity, startle response, learning/memory ability, or activity related with one's motivation) and/or physiological (e.g., brain gene expression, enzymatic activity, or neuronal cell damage) changes [124,126,156-165]. Interestingly, the effects of developmental MeHg exposure may be different depending on sex or age of test animals at the time of DNT evaluation. As an example, in one study, female rat offspring maternally exposed to $\mathrm{MeHg}(0.5 \mathrm{mg} / \mathrm{kg} / \mathrm{day}$, from GD7 until postnatal Day 21) exhibited a decrease in vertical activity when tested at 2 months of age, while the activity of male offspring increased at the age of 3 months [126]. In another study, Beyrouty et al. [157] observed abnormal movement in female offspring, but not in males, when mothers were treated with $\mathrm{MeHg}$ $(0.5 \mathrm{mg} / \mathrm{kg} /$ day from 4 weeks before mating until GD20) in response to auditory stimulation compared to control. Moreover, a significant decrease in monoamine oxidase enzyme activity was also detected in the brainstem of female offspring maternally treated with a higher dose of $\mathrm{MeHg}(1 \mathrm{mg} / \mathrm{kg} / \mathrm{day})$, while this change of enzymatic activity did not appear significant in male offspring [157]. Studies conducted in the past five years on the neurotoxic effects of $\mathrm{MeHg}$ exposure with rodent models in developmental stages are summarized in Table 1.

The underlying mechanisms of MeHg DNT are not yet fully understood, but may be associated with interference of receptor activities involved in signaling pathways, oxidative stress defense mechanism, or the differentiation of the BBB [159,162-165].

\subsection{Lead}

Lead $(\mathrm{Pb})$ is a metallic element, which occurs naturally in the environment. $\mathrm{Pb}$, with a common oxidation state of $2+$ or $4+$, exists as organic $\mathrm{Pb}$ and inorganic $\mathrm{Pb}$, with humans being exposed to both forms. Human exposure to $\mathrm{Pb}$ increased extensively with its utilization in production of industrial chemicals (e.g., as a gasoline additive and in Pb-based paint) during the 1920s-1970s. Since the mid-1970s, the addition of $\mathrm{Pb}$ for fuel or paint production has been restricted in many of the developed countries including the US because of the increasing health concerns associated with $\mathrm{Pb}$ exposure on various organ systems including the CNS. However, even after the withdrawal, environmental $\mathrm{Pb}$ exposure is still an ongoing concern in that exposure to low doses of $\mathrm{Pb}$ is reported to be associated with neurodevelopmental alterations in children $[2,3]$.

Neurotoxic consequences of a developmental $\mathrm{Pb}$ exposure was noticed as early as the 1970s by studies conducted with subjects who were exposed to relatively high levels of $\mathrm{Pb}$ (e.g., a mean 
concentration of $202.1 \mu \mathrm{g} \mathrm{Pb} / \mathrm{g}$ dentine) [166,167]. These early studies reported that Pb-exposed children exhibited several features of neurodevelopmental deficits including cognitive decline, decreased IQ score, and learning disabilities [166,167]. Later, studies with children exposed to much lower levels of $\mathrm{Pb}$ also detected similar neurodevelopmental deficits [168,169]. One noticeable example is a prospective study conducted by Bellinger et al. [168]. In this study, a cohort of 249 children was categorized into three groups according to their prenatal $\mathrm{Pb}$ exposure levels estimated by measuring cord blood $\mathrm{Pb}$ concentration ranging from below $3 \mu \mathrm{g} / \mathrm{dL}$ though $10 \mu \mathrm{g} / \mathrm{dL}$ or above. Bellinger et al. [168] then evaluated the Mental Development Index (of Bayley Scales of Infant Development) of subjects included in each of the three groups at different stages of development until 2 years of age. Subjects prenatally exposed to higher levels of $\mathrm{Pb}$ (cord blood $\mathrm{Pb}$ level of $10-25 \mu \mathrm{g} / \mathrm{dL}$ ) showed poor performance in the cognitive development test during 2 years of development compared to those with lower cord blood $\mathrm{Pb}$ levels (below $10 \mu \mathrm{g} / \mathrm{dL}$ ), suggesting a negative impact of prenatal $\mathrm{Pb}$ exposure on early neurodevelopment [168].

To date, studies continue to report negative impacts of low-dose $\mathrm{Pb}$ exposure (i.e., blood $\mathrm{Pb}$ level below $10 \mu \mathrm{g} / \mathrm{dL}$ ) on early neurodevelopment, leading to lowered IQ, increased ADHD risk, and poor academic achievement in children and cognitive decline in infants [2,3,170,171]. Canfield et al. [3] measured blood $\mathrm{Pb}$ levels of children at age 6-60 months and then examined their IQ scores at age 3 and 5 years using the Stanford-Binet Intelligence Scale. Researchers found a linear relationship between a 4.6-point decline in children's IQ and every $10 \mu \mathrm{g} / \mathrm{dL}$ increase of blood Pb level using a lifetime average [3]. In addition, Braun et al. [2] reported a relationship between a developmental $\mathrm{Pb}$ exposure at blood $\mathrm{Pb}$ levels in children below $10 \mu \mathrm{g} / \mathrm{dL}$ and an increased risk of ADHD. In this study, it was shown that children at the ages of 4-15 with higher levels of $\mathrm{Pb}$ in the blood $(2-5 \mu \mathrm{g} / \mathrm{dL})$ were at a 4.5-fold increased risk for ADHD compared to those with low blood Pb levels (below the limit of detection through $0.7 \mu \mathrm{g} / \mathrm{dL}$ ) [2].

In addition, nonhuman primate studies have also shown the relationship between early-life $\mathrm{Pb}$ exposure and behavioral alterations [172-175]. For example, in Bushnell and Bowman [172,173], developmental $\mathrm{Pb}$ exposure resulted in poor performance on reversal learning tasks. In Laughlin et al. [176], it was also reported that monkeys developmentally exposed to $\mathrm{Pb}$ exhibited altered social behavior at an early age.

A number of mechanisms of $\mathrm{Pb}$ DNT have been proposed and while an extensive number of studies have been conducted, the mechanisms of $\mathrm{Pb} \mathrm{DNT}$ are not yet completely understood. To this end, several in vivo rodent studies have been performed in immature brains, relating developmental $\mathrm{Pb}$ exposure with alterations of cholinergic-, catecholaminergic, or glutamatergic neurotransmitter systems [177-180]. Several studies have related developmental $\mathrm{Pb}$ exposure and the function of glutamate receptor or its subtypes (e.g., $\mathrm{N}$-methyl-D-aspartate (NMDA) receptor subtypes and metabotropic glutamate receptors) [180-183]. The functional importance of glutamate receptors is known with their involvement in excitatory signal transmission and learning/memory function [184]. Thus, the focus of many Pb DNT mechanistic studies has been on defining expression alterations of glutamate receptors. Accordingly, some progress has been made with studies identifying increased sensitivity to NMDA or altered expression of glutamate receptors in brain samples (e.g., the hippocampus) following developmental $\mathrm{Pb}$ exposure in rat models [180-183]. Studies conducted in the 
past five years on the neurotoxic effects of $\mathrm{Pb}$ exposure with rodent models in developmental stages are summarized in Table 1.

\subsection{Mixtures}

There are also several studies completed evaluating DNT of metal mixtures with a specific consideration given to mixtures of arsenic, $\mathrm{MeHg}$, or $\mathrm{Pb}$ with each other or with other metals such as manganese and cadmium [119,185-187] or with organic chemicals such as polychlorinated biphenyls and polybrominated diphenyl ethers (PBDEs) [126,188,189]. Combined with the increasing evidence in recent years, it has been revealed that developmental exposure to neurotoxic chemical mixtures may have additive or synergistic adverse effects. However, the various outcomes and complex mechanisms of DNT induced by co-exposure to multiple chemicals still remain largely unknown.

\section{DNT Studies Using the Zebrafish Model System}

\subsection{Application of the Zebrafish Model in Various Chemical-Induced DNT Studies}

The zebrafish model has been applied in DNT research using a variety of chemical compounds including different classes of pesticides, ethanol, PBDEs, and other emerging environmental contaminants (e.g., nanoparticles). These studies have demonstrated DNT of various substances, among which major findings highlighting the potential of the zebrafish model, which are introduced in this section.

Several studies have addressed zebrafish as a suitable model for testing pesticide-induced neurotoxicity appearing in very early stages of development $[45,46,49,53,57-59,64,65]$. Studies on organophosphorus pesticides, especially chlorpyrifos, indicated that developmental exposure to this chemical induced neurobehavioral changes in the zebrafish [46,57,65]. Eddins et al. [46] examined effects of chlorpyrifos exposure on levels of neurochemicals of zebrafish (144 hpf), showing decreased dopamine and serotonin levels but not norepinephrine levels. Effects of a developmental chlorpyrifos exposure or exposure to the metabolites of chlorpyrifos on acetylcholine esterase (AChE) activity were also assessed. In Yen et al. [65], exposure to chlorpyrifos significantly decreased AChE activity of zebrafish (120 hpf). On the other hand, in Yang et al. [64], it was the oxon metabolite of chlorpyrifos, not chlorpyrifos, which induced a significant decrease in AChE activity (48 and $72 \mathrm{hpf}$ ) with alteration of swimming activity (72 hpf) in wild-type, and growth inhibition of axons in transgenic zebrafish (72 hpf).

DNT of pyrethroids and other pesticides (e.g., cartap, fenvalerate, fipronil, thiocyclam) has also been tested in the zebrafish model [45,49,53,58,59]. DeMicco et al. [45] observed abnormal movement of body, which is described as "spastic movement", in the zebrafish ( $96 \mathrm{hpf}$ ) developmentally exposed to Type I (bifenthrin, permethrin, and resmethrin) or Type II pyrethroids ( $\lambda$-cyhalothrin, cypermethrin, and deltamethrin). Interestingly, body curvature observed in zebrafish (144 hpf) developmentally treated by either Type I pyrethroids (bifenthrin and permethrin) or three Type II pyrethroids was also explained as an indication of neurotoxicity, not as a result of morphological alteration. This interpretation, both the spasms and the curvature as consequences of DNT, turned out to be rational since registration of diazepam (a $\gamma$-aminobutyric acid $[\mathrm{GABA}]_{\mathrm{A}}$ receptor antagonist) or MS-222 (a sodium channel blocker) after deltamethrin treatment alleviated the abnormal movements and/or the curvature [45]. In another pyrethroid study, zebrafish exposed to cypermethrin exhibited apoptotic cell 
death (96 hpf) in the CNS region (brain and spinal cord) [58]. Cypermethrin exposure also altered activities of enzymes responsive to oxidative stress (i.e., superoxide dismutase and catalase), level of malondialdehyde, and expression of a gene involved in DNA repair (i.e., 8-oxoguanine DNA glycosylase ( ogg1)), suggesting the neurotoxic mechanisms related to the pathways of oxidative stress production and DNA-repair [58]. Similar effects were shown in the study of fenvalerate to which exposure resulted in apoptosis in the brain region of embryo and larval zebrafish [49]. In this study, changes in superoxide dismutase activity and expression of distal-less homeobox 2 ( $d l x 2$, a gene involved in neural differentiation) as well as oggl were observed, implying the involvement of oxidative stress generation and alteration of $d l x 2$ and ogg1 related biological processes in mechanisms of fenvalerate-induced DNT [49].

The zebrafish model has been applied for testing the developmental neurotoxic effects of exposure to chemicals related to Parkinson's disease, including 1-methyl-4-phenyl-1,2,3,6-tetrahydropyridine (MPTP), paraquat, and rotenone [37,62]. It seems clear that MPTP induces neurobehavioral changes and/or neuronal decrease in the developing zebrafish [37,43,62]. In Bretaud et al. [37], while paraquat or rotenone treatment did not induce significant changes, MPTP exposure induced decreases in swimming speed and in the number of dopaminergic neurons in the diencephalon of zebrafish at $168 \mathrm{hpf}$ and $120 \mathrm{hpf}$, respectively. Being a well-defined developmental neurotoxicant, MPTP was also used as a positive compound by Chen et al. [43] in which sodium benzoate exposure resulted in decreased dopamine neuronal expression of tyrosine hydroxylase and dopamine transporter at $72 \mathrm{hpf}$, and altered larval locomotive activity at $144 \mathrm{hpf}$.

There are zebrafish studies on ethanol-induced neurotoxicity, showing the effects of developmental ethanol exposure on several neurotoxicological endpoints (e.g., altered behavior, apoptotic cell death, decreased retino-tectal projection area) and also the underlying mechanism [38,42,48,51]. Especially, apoptotic cell death occurring in the head area has been pronounced as one of the neurotoxic effects caused by developmental ethanol exposure in the zebrafish [38,48,51]. For example, in Flentke et al. [48], ethanol toxicity was investigated in regard to the association between ethanol exposure and fetal alcohol spectrum disorders. Flentke et al. [48] showed that ethanol exposure for $3 \mathrm{~h}$ resulted in apoptotic death of neural crest cells related to the calcium calmodulin-dependent protein kinase II signaling pathway.

Zebrafish studies have revealed the neurotoxic effects of exposure to PBDEs (e.g., DE-71, BDE-47, BDE-49), showing alteration in neurobehavior, genetic expression, cholinergic system and/or axonal growth [39-41,52]. As an example, in Chen et al. [39], zebrafish (120 hpf) developmentally exposed to DE-71 exhibited altered locomotor movement, increased AChE activity, and decreased expression of nervous system genes (myelin basic protein, al-tubulin, and sonic hedgehog a). Parental exposure to DE-71 (for 150 days) also induced changes in neurobehavior, CNS gene expression (myelin basic protein, synapsin IIa, $\alpha 1$-tubulin), and the cholinergic system but with decreased AChE activity in $\mathrm{F}_{1}$ offspring at $96 \mathrm{hpf}[40]$.

As shown in the research above, the zebrafish has a potential to be applied for testing DNT of a broad range of chemicals. However, a limited number of zebrafish studies have been conducted on influences of exposure to other substances (e.g., TCDD, cadmium, nanoparticles, and valproate) on neurobehavior or neurogenesis in the developmentally exposed zebrafish $[42,44,50,54,63,66]$. To this end, there has been a need to develop the strengths and further the application of the zebrafish as a 
model organism for DNT testing. Studies have suggested endpoints which can serve as indicators in DNT screening of a variety of chemicals, which are described in the below section.

\subsection{The Zebrafish as a Potential Tool for Chemical-Induced DNT Screening}

The zebrafish model allows screening of multiple chemical DNT within a few days through examination of cellular (apoptosis) or specific neuronal proliferation (neuronal development or survival) appearing in the brain region by utilizing simple staining methods such as acridine orange (AO) staining or immunostaining [60,61]. For example, Ton et al. [61] suggested the zebrafish as a screening tool for DNT assessment, showing that measurement of cell death in the brain can be a useful endpoint using the zebrafish in the early life stage (96 hpf). Zebrafish were treated with five test chemicals (e.g., atrazine, 2,4-D, DDT, dieldrin, and nonylphenol), one teratogen (TCDD), or one negative compound for neurotoxicity (malathion) and then axonal tracts, catecholaminergic neurons, and apoptotic cell death occurring in the brain region visualized [61]. DNT was differentiated from teratogenic effects by obtaining the teratogenic index of each chemical. The results specified 2,4-D, dieldrin, and nonylphenol as developmental neurotoxicants among the seven chemicals tested [61].

Fan et al. [47] and Cowden et al. [42] suggested the examination of the quantitative expression of selected genes or the retino-tectal projection area as potential DNT endpoints. The relevance of these endpoints was proven using ethanol and/or valproate as model neurotoxicants. Fan et al. [47] provided gene expression profiles of ten nervous system genes (e.g., glial fibrillary acidic protein, myelin basic protein, nestin, synapsin IIa) with control genes (ribosomal protein L13A and elongation factorl alpha) during zebrafish development ( $\approx 6$ days), so that this information can be used for future DNT screening.

Neurobehavioral alterations are a popular neurotoxicological endpoint in DNT studies using the zebrafish. With the small size, transparency, and ex vivo embryonic development of the zebrafish, live tracking of zebrafish behaviors using video recording tools is available from the early embryonic stages. A recent study by Kalueff et al. [190] further defined major behaviors of zebrafish to aid in the interpretation of zebrafish behavioral changes as phenotypes of neurological alterations. In the field of DNT research, the zebrafish neurobehavioral changes observed as endpoints can be grossly divided into three categories: spontaneous movement, touch-responsive movement, and locomotor activity induced without touch stimulation. These endpoints have been the basis for the development of methods for screening chemical-induced DNT in recent studies [42,55,56]. For example, as an attempt to provide a method for DNT screening using zebrafish, Selderslaghs et al. [56] examined behaviors of embryos (spontaneous movement) and larvae (swimming activity). These neurobehavioral endpoints were observed following exposure to seven chemicals with known DNT (e.g., acrylamide, bisphenol A, chlorpromazine, or $\mathrm{MeHg}$ ) or three negative substances (e.g., acetaminophen, omeprazole, or saccharin). These results were then compared to the existing literature on the DNT of these chemicals [56]. Test results using all chemicals but omeprazole corresponded to existing animal data, showing the potential of the zebrafish in early life stages as a tool for screening chemical-induced DNT [56].

Overall with the recent gains in knowledge on zebrafish neurobehavior and transcriptional regulation, behavioral assays and transcriptional assessments provide comparable DNT data to traditional rodent model studies. Furthermore, various strengths of the zebrafish are being utilized to further the understanding of DNT at endpoints that are not as easily assessed in rodent models. For 
example, the ex vivo embryonic development allows microscopic examination of developing axons immediately after fertilization, serving as a valuable indicator of DNT which is not as easily assessed in other vertebrate model systems.

\subsection{DNT Studies of Arsenic, Methylmercury, or Lead Using the Zebrafish}

The zebrafish has been utilized in several studies on the DNT of arsenic, $\mathrm{MeHg}$, and $\mathrm{Pb}$ (Table 1). In these studies, the neurotoxic consequences of developmental metal exposures and/or the underlying mechanisms of metal DNT have been investigated from various angles (e.g., axonal growth inhibition, transcriptomic alterations, or neurobehavioral changes). In this section, we review the progress made in DNT studies on the metalloid arsenic and the two metals $\mathrm{MeHg}$ and $\mathrm{Pb}$ using the zebrafish as a test organism to support further studies of DNT using this model system. As an effort to differentiate developmental toxicity from DNT, overt signs of toxicity such as altered hatchability of embryo, lethality, or gross morphological (e.g., craniofacial alteration) or histological (e.g., organ edema) changes are excluded from the review unless the neurotoxic origin of those effects are clarified.

There are a few studies describing the effects or mechanisms of neurotoxicity associated with a developmental exposure to arsenic. In a study by Li et al. [120], zebrafish embryos were exposed to either a control treatment or various concentrations of sodium arsenite from $4 \mathrm{hpf}$. To investigate the effects of arsenite exposure on early neurodevelopment, the zebrafish embryos were subjected to either simple microscopic observations at $30 \mathrm{hpf}$ or immunostaining at $48 \mathrm{hpf}$ [120]. The former experiment was conducted to observe the reflexive actions of embryos in response to light stimulation, revealing that the frequency of motions made by embryos developmentally treated with 2 or $5 \mathrm{mM}$ arsenite decreased significantly compared to the control zebrafish [120]. As the zebrafish in very early stages of development has a relatively simple neuronal network, the observation of the reflexive movement may reflect the altered neuronal function derived from arsenite exposure, not the secondary outcome of non-DNT (e.g., growth retardation). In the immunostaining experiment, axonal tracts of zebrafish embryos were visualized using acetylated $\alpha$-tubulin $(\alpha$-AT) antibody and showed altered growth patterns of axons in the brain and spinal cord of zebrafish exposed to $2 \mathrm{mM}$ of arsenite compared to those in the control treatment [120]. Furthermore, researchers also found that exposure to $2 \mathrm{mM}$ arsenite induced changes in patterns of cell proliferation, cell death, and DNA methylation in developing zebrafish at 24 and/or 48 hpf using various methods including proliferating cell nuclear antigen (PCNA) labeling, terminal deoxynucleotidyl transferase dUTP nick end labeling (TUNEL) assay, and 5-methylcytidine labeling [120]. Based on these observations, it might be reasonable to assume that arsenite DNT is related to the altered biological processes strictly regulated by proper cell proliferation, apoptosis, or DNA methylation during normal embryonic development. To generalize this assumption, however, additional investigations into the molecular mechanism of arsenite DNT need to be performed to clarify that the effects observed in the zebrafish are the consequences of DNT and not of teratogenicity. A follow-up study by Li et al. [191] investigated the mechanisms of arsenic DNT with a focus on the activity of zebrafish Dvr1, which is involved in axis formation (known as growth differentiation factor 1 (GDF1) in mammals). In this study, quantitative polymerase chain reaction (qPCR) and whole mount in situ hybridization techniques were utilized to detect the levels of Dvr1 expression in the developing zebrafish. The results of this study showed a decrease in Dvr1 
expression in $2 \mathrm{mM}$ sodium arsenite treated embryos compared to those in the control group at 6 hpf in both of the experiments [191]. To further investigate the association between Dvr1 function and early development of the zebrafish nervous system, researchers injected a Dvr1 morpholino (MO) with or without plasmids encoding Dvr1 homolog (e.g., mouse GDF1) [191]. By performing this simple MO injection into the embryo, expression of a specific gene of interest can be silenced in the zebrafish. The generated Dvr1 morphants were then subjected to $\alpha$-AT staining at $48 \mathrm{hpf}$ and showed impaired neural development in the brain, trunk, and tail compared to embryos in the control treatment (i.e., not genetically manipulated embryos) [191]. In the same immunostaining experiment using embryos co-treated with Dvr1 MO and plasmids, the expression of mouse GDF1 alleviated the neurodevelopmental effects of Dvr1 knockdown, suggesting the involvement of Dvr1 in the mechanism of arsenic DNT in the zebrafish [191].

Long et al. [192] identified the expression of abcc5 (ATP-binding cassette transporter), which plays a role in cellular signaling and protection from xenobiotics, in the zebrafish embryo with or without an exposure to heavy metals including arsenic, mercury, and $\mathrm{Pb}$. Firstly, Long et al. [192] characterized quantitative and spatial expression of $a b c c 5$ by using qPCR and whole mount in situ hybridization, revealing that $a b c c 5$ was expressed in the lens and brain during embryogenesis (24, 48, and $72 \mathrm{hpf}$ ). The level of abcc5 expression was then evaluated in embryos treated with different concentrations of metals, including sodium arsenate $(100 \mu \mathrm{M}), \mathrm{Hg}$ chloride $(0.5 \mu \mathrm{M})$, or Pb nitrate $(50 \mu \mathrm{M})$ [192]. qPCR results indicated that each metal exposure (through 24 to $48 \mathrm{hpf}$ ) resulted in a significant increase in quantitative $a b c c 5$ expression [192]. The pattern of $a b c c 5$ expression observed without metal exposure implies that this gene may have a role in distinctive regions including the brain during embryogenesis. Although it needs to be further elucidated, considering the function of $a b c c 5$ is to transport cGMP in signal transduction, one can speculate that expression alterations of abcc5 induced by metal exposure may interfere with important biological processes such as neurodevelopment.

The zebrafish model system was also applied to investigate MeHg DNT. Hassan et al. [193] observed a significant reduction of cellular proliferation occurring in the neural tube of zebrafish developmentally exposed to 10,50 , or $80 \mu \mathrm{g} / \mathrm{L}(\approx 0.4 \mu \mathrm{M}) \mathrm{MeHg}$ at $30 \mathrm{hpf}$ using PCNA staining. Cuello et al. [194] investigated the effects of $\mathrm{MeHg}$ exposure on zebrafish development at the protein level using iTRAQ (isobaric tags for relative and absolute quantification). Altered expression of proteins involved in calcium binding (e.g., parvalbumin-2 and parvalbumin 9, and parvalbumin isoform 1d) was observed in the zebrafish treated with $25 \mu \mathrm{g} / \mathrm{L}(\approx 0.1 \mu \mathrm{M}) \mathrm{MeHg}$ from 72 to $144 \mathrm{hpf}$, suggesting the disturbance of calcium homeostasis as an important mechanism of $\mathrm{MeHg}$ toxicity. More recently, Ho et al. [125] treated embryos with $60 \mu \mathrm{g} / \mathrm{L}(\approx 0.3 \mu \mathrm{M}) \mathrm{MeHg}$ from 48 to $72 \mathrm{hpf}$ and then conducted microarray analysis, which enables global detection of gene expression changes in the zebrafish. Researchers then conducted a whole mount in situ hybridization with 88 genes that showed substantial expression changes in the microarray analysis and confirmed expression alterations of 60 of the 88 genes [125]. The data from the in situ hybridization experiments also allowed further grouping of genes according to their expression patterns shown in different tissues. In this analysis, 24 of the 88 genes had specific expression alterations in the brain region [125]. These 24 genes expressed in the brain were involved in a variety of biological activities including transcriptional regulation, development, and transport processes, implying possible biological disturbances in the zebrafish brain affected by developmental $\mathrm{MeHg}$ exposure [125]. The information obtained from this transcriptomic 
analysis is valuable since there is a lack of basic data about potential molecular targets of $\mathrm{MeHg}$ neurotoxicity. Thus, this data can assist in identifying targets for later in-depth studies using the zebrafish to further define the molecular mechanisms of MeHg DNT toxicity.

Several Pb DNT studies have been carried out using the zebrafish, presenting various signs of neurodevelopmental alterations in $\mathrm{Pb}$ exposed subjects (reviewed in [195]). Low concentrations tested in the $\mathrm{Pb}$ exposure studies described below show that the zebrafish is indeed a very sensitive in vivo test model for DNT assessment. For example, Peterson et al. [128] evaluated global gene expression changes in developing zebrafish in response to a low-dose $\mathrm{Pb}$ exposure. Microarray analysis was performed with embryos treated with $100 \mathrm{ppb}(\approx 0.5 \mu \mathrm{M}) \mathrm{Pb}$ through the end of embryogenesis, resulting in significant expression alterations of 55 genes engaged in processes related to nervous system development/functioning and neurological diseases [128]. Western blot analysis revealed significant changes in expression of several target proteins including metallothionein-2, FRY-like, and reelin [128]. The results of this study are noteworthy in revealing that a low-dose of $\mathrm{Pb}$ was sufficient to induce expression alterations of genes/proteins involved in the zebrafish nervous system. In addition, it is also important to note that the alterations detected at $72 \mathrm{hpf}$ were not present at $120 \mathrm{hpf}$, implying that the effects of a developmental $\mathrm{Pb}$ exposure might be time point specific. It is yet unclear whether the expression alterations of nervous system genes observed at $72 \mathrm{hpf}$ are reflective of transient effects of $\mathrm{Pb}$ exposure or not. To answer this question, further analyses of global changes of gene expression appearing at stages earlier than $72 \mathrm{hpf}$ and later than $120 \mathrm{hpf}$ need to be performed.

In a follow-up study, Peterson et al. [196] assessed the expression of zebrafish reln (equivalent to human reelin that is known to be involved in neuronal development and diseases). Zebrafish embryos were exposed to up to $100 \mathrm{ppb} \mathrm{Pb}$ acetate shortly after fertilization through 24-96 hpf, and then subjected to whole mount in situ hybridization or qPCR analysis to evaluate expression alteration of zebrafish reln [196]. In the in situ hybridization experiment, expression of reln was noticeable in the CNS region beginning at $24 \mathrm{hpf}$, while no spatial expression alterations were observed in response to the $\mathrm{Pb}$ exposure. A significant decrease in reln expression occurred only in embryos treated with $100 \mathrm{ppb} \mathrm{Pb}$ at $60 \mathrm{hpf}$, without significant changes in brain morphology or brain cell apoptosis. These findings suggest a time point specific role of this gene that might be involved in neurotoxic mechanisms other than brain morphogenesis [196]. Considering the absence of apoptotic cell death in the brain, which is one of the frequently used indicators of neurotoxicity in zebrafish studies, focus of future studies needs to be placed on different mechanisms of neurotoxicity.

In an additional follow-up study, the effect of $\mathrm{Pb}$ exposure on axonal growth in the developing zebrafish was studied following exposure to $100 \mathrm{ppb} \mathrm{Pb}$ acetate at several time points between 18-36 hpf by $\alpha$-AT staining and showed a significant decrease in axonal density in $\mathrm{Pb}$ exposed embryos at 18, 20, or 24 hpf [70]. The genetic mechanisms underlying this $\mathrm{Pb}$-induced axonal density decrease were investigated by measuring quantitative expression of genes involved in axon guidance in embryos exposed to $100 \mathrm{ppb} \mathrm{Pb}$ through 14-36 hpf. The qPCR analysis revealed that expression of sonic hedgehog $a$ and ephrin type-A receptor $4 b$ were significantly down-regulated at 14 and $16 \mathrm{hpf}$, respectively [70]. On the other hand, netrin2 expression increased significantly at 30 and 36 hpf, suggesting the involvement of netrin2 in regulating axonal growth in response to $\mathrm{Pb}$ neurotoxicity at early developmental stages [70]. 
Recently Wirbisky et al. [69] investigated the effects of $\mathrm{Pb}$ acetate exposure (up to $100 \mathrm{ppb}$, up to $72 \mathrm{hpf}$ ) on the GABAergic system of embryonic zebrafish using qPCR and High Performance Liquid Chromatography (HPLC). In the qPCR analysis, $\mathrm{Pb}$ treated embryos exhibited time point specific expression alterations of genes involved in GABA production (gad2, gad1b), transport (gat-1, gat-3, vgat), and GABA receptors (gabral, gabbrla) throughout embryogenesis [69]. GABA measurement by HPLC revealed that embryonic $\mathrm{Pb}$ exposure also induced fluctuation of GABA levels with an increase in GABA at $48 \mathrm{hpf}$ and a decrease in GABA at $72 \mathrm{hpf}$ [69]. These results suggest that $\mathrm{Pb}$ exposure interferes with the GABAergic system in the zebrafish during embryonic developmental stages with different patterns of genetic expression and GABA level fluctuations. In regards to the function of GABA which can be either excitatory or inhibitory at different embryonic developmental stages, future observations at narrower ranges of developmental time points may explain the importance of the GABAergic system as a mechanism of Pb-induced DNT.

Developmental $\mathrm{Pb}$ exposure also causes neurobehavioral changes in the zebrafish. In Rice et al. [131], embryos were treated with up to $30 \mathrm{nM}$ of $\mathrm{Pb}$ chloride through $24 \mathrm{hpf}$ and then subjected to a neurobehavioral test at $168 \mathrm{hpf}$. The behavioral changes of the zebrafish were evaluated on several parameters reflecting altered movement in response to different frequencies of tapping stimulation (i.e., one tap/s or four taps/s), showing that zebrafish developmentally treated with $30 \mathrm{nM}$ of $\mathrm{Pb}$ exhibited altered responses under both the one and four taps/second frequency stimulation [131]. Rice et al. [131] also provided a probable mechanistic interpretation of the behavioral changes including altered sensitivity of mechanosensory neuromasts, function of neurons involved in signal integration, or neurotransmitter signaling, albeit inclusive. In another study Chen et al. [132] treated zebrafish with up to $1 \mathrm{mg} / \mathrm{L}(\approx 5 \mu \mathrm{M}) \mathrm{Pb}$ acetate from 6-8 hpf and monitored spontaneous movement from 20 until $30 \mathrm{hpf}$, showing that spontaneous activity of embryos exposed to $1 \mathrm{mg} / \mathrm{L}$ of $\mathrm{Pb}$ significantly decreased at most of the tested time points. Chen et al. [132] also examined behavioral changes of zebrafish developmentally treated with lower concentrations of $\mathrm{Pb}$ acetate (up to $0.1 \mathrm{mg} / \mathrm{L}$ $(\sim 0.5 \mu \mathrm{M}))$ starting from $6 \mathrm{hpf}$ until the time of evaluation. In the test conducted under constant light or dark condition at $120 \mathrm{hpf}$, zebrafish developmentally exposed to $0.1 \mathrm{mg} / \mathrm{L} \mathrm{Pb}$ showed a significant decrease and increase in mean swimming speed under light and dark condition, respectively [132]. The mechanisms of $\mathrm{Pb}$ DNT causing the inconsistent change of larval swimming activity as well as the alteration of spontaneous movement are largely unknown. Considering the sensitivity of the zebrafish embryo and larva, further elucidation may be necessary to discriminate the behavioral alteration caused by different experimental conditions from the $\mathrm{Pb}$-induced neurobehavioral effects. Taken together, the $\mathrm{Pb}$ DNT studies using the zebrafish model have shown the neurotoxic effects of a low-dose $\mathrm{Pb}$ exposure at specific time points. Information about molecular targets of $\mathrm{Pb} \mathrm{DNT}$ in the zebrafish allows further investigation of mechanisms involved in $\mathrm{Pb}$-induced $\mathrm{DNT}$. Future studies on behavioral phenotypes and underlying molecular mechanisms at expanded developmental time points or with lower doses of $\mathrm{Pb}$ will aid in the understanding of $\mathrm{Pb} \mathrm{DNT}$ in the zebrafish.

\section{Conclusions}

The zebrafish has traditionally been a popular model in the field of developmental biology with current expansion into all areas of biological research. The zebrafish presents a number of strengths 
as an in vivo laboratory model including the use as a complementary vertebrate model for DNT assessment. Furthermore, the application of the zebrafish as a complementary model in DNT studies is supported by published studies investigating the DNT of the known neurotoxicants arsenic, MeHg, and $\mathrm{Pb}$. To facilitate the application of the zebrafish model in DNT testing, further studies need to be conducted on exposure kinetics of various substances to determine exposure doses per embryo or larva. A few studies have started to include this analysis (e.g., [69,70]), but more work is needed in this area to understand dose and exposure kinetics. In addition, chorionation or dechorionation status at the time of chemical exposure may also affect the degree of chemical absorption by the embryo. Additionally, there is a need for validation of existing endpoints to distinguish DNT from developmental toxicity (e.g., differentiation of behavior from neurobehavior) and for the development of novel markers which can be used as direct indicators of DNT in the zebrafish. Overall, with future investigations, the use of the zebrafish model system will assist in the screening of developmental neurotoxicants and ultimately facilitate our understanding of DNT mechanisms.

\section{Acknowledgments}

The authors thank Jun Zhang for assistance with the zebrafish images.

\section{Author Contributions}

Both authors (Jinyoung Lee and Jennifer L. Freeman) worked collaboratively on all aspects of the manuscript.

\section{Conflicts of Interest}

The authors declare no conflict of interest.

\section{References}

1. Bellinger, D.C. Prenatal Exposures to Environmental Chemicals and Children's Neurodevelopment: An Update. Saf. Health Work 2013, 4, 1-11.

2. Braun, J.M.; Kahn, R.S.; Froehlich, T.; Auinger, P.; Lanphear, B.P. Exposures to environmental toxicants and attention deficit hyperactivity disorder in U.S. children. Environ. Health Perspect. 2006, 114, 1904-1909.

3. Canfield, R.L.; Henderson, C.R., Jr.; Cory-Slechta, D.A.; Cox, C.; Jusko, T.A.; Lanphear, B.P. Intellectual impairment in children with blood lead concentrations below 10 microg per deciliter. N. Engl. J. Med. 2003, 348, 1517-1526.

4. Harrington, R.A.; Lee, L.C.; Crum, R.M.; Zimmerman, A.W.; Hertz-Picciotto, I. Prenatal SSRI Use and Offspring with Autism Spectrum Disorder or Developmental Delay. Pediatrics 2014, doi:10.1542/peds.2013-3406.

5. Dobbing, J. Vulnerable Periods in Developing Brain. In Brain, Behaviour, and Iron in the Infant Diet; Dobbing, J., Ed.; Springer: London, UK, 1990; pp. 1-17.

6. Giussani, D.A. The vulnerable developing brain. Proc. Natl. Acad. Sci. USA 2011, 108, 2641-2642. 
7. Perera, F.; Herbstman, J. Prenatal environmental exposures, epigenetics, and disease. Reprod. Toxicol. 2011, 31, 363-373.

8. Smart, J.; Dobbing, J.; Adlard, B.; Lynch, A.; Sands, J. Vulnerability of developing brain: Relative effects of growth restriction during the fetal and suckling periods on behavior and brain composition of adult rats. J. Nutr. 1973, 103, 1327-1338.

9. Fagiolini, M.; Jensen, C.L.; Champagne, F.A. Epigenetic influences on brain development and plasticity. Curr. Opin. Neurobiol. 2009, 19, 207-212.

10. Bouayed, J.; Desor, F.; Rammal, H.; Kiemer, A.K.; Tybl, E.; Schroeder, H.; Rychen, G.; Soulimani, R. Effects of lactational exposure to benzo[alpha]pyrene (B[alpha]P) on postnatal neurodevelopment, neuronal receptor gene expression and behaviour in mice. Toxicology 2009, 259, 97-106.

11. Kleiber, M.L.; Mantha, K.; Stringer, R.L.; Singh, S.M. Neurodevelopmental alcohol exposure elicits long-term changes to gene expression that alter distinct molecular pathways dependent on timing of exposure. J. Neurodev. Disord. 2013, 5, 6.

12. Billstedt, E.; Gillberg, I.C.; Gillberg, C. Autism in adults: Symptom patterns and early childhood predictors. Use of the DISCO in a community sample followed from childhood. J. Child Psychol. Psychiatry 2007, 48, 1102-1110.

13. Kessler, R.C.; Adler, L.A.; Barkley, R.; Biederman, J.; Conners, C.K.; Faraone, S.V.; Greenhill, L.L.; Jaeger, S.; Secnik, K.; Spencer, T.; et al. Patterns and predictors of attention-deficit/hyperactivity disorder persistence into adulthood: Results from the national comorbidity survey replication. Biol. Psychiatry 2005, 57, 1442-1451.

14. Grandjean, P.; Landrigan, P.J. Developmental neurotoxicity of industrial chemicals. Lancet 2006, 368, 2167-2178.

15. Grandjean, P.; Landrigan, P.J. Neurobehavioural effects of developmental toxicity. Lancet Neurol. 2014, 13, 330-338.

16. Chen, A.; Dietrich, K.N.; Huo, X.; Ho, S.M. Developmental neurotoxicants in e-waste: An emerging health concern. Environ. Health Perspect. 2011, 119, 431-438.

17. Mergler, D.; Anderson, H.A.; Chan, L.H.; Mahaffey, K.R.; Murray, M.; Sakamoto, M.; Stern, A.H. Panel on health risks and toxicological effects of methylmercury. Methylmercury exposure and health effects in humans: A worldwide concern. Ambio 2007, 36, 3-11.

18. Mukherjee, A.; Sengupta, M.K.; Hossain, M.A.; Ahamed, S.; Das, B.; Nayak, B.; Lodh, D.; Rahman, M.M.; Chakraborti, D. Arsenic contamination in groundwater: A global perspective with emphasis on the Asian scenario. J. Health Popul. Nutr. 2006, 24, 142-163.

19. Smith, A.H.; Lingas, E.O.; Rahman, M. Contamination of drinking-water by arsenic in Bangladesh: A public health emergency. Bull. World Health Organ. 2000, 78, 1093-1103.

20. Tong, S.; von Schirnding, Y.E.; Prapamontol, T. Environmental lead exposure: A public health problem of global dimensions. Bull. World Health Organ. 2000, 78, 1068-1077.

21. Lidsky, T.I.; Schneider, J.S. Lead neurotoxicity in children: Basic mechanisms and clinical correlates. Brain 2003, 126, 5-19.

22. Landrigan, P.J. What causes autism? Exploring the environmental contribution. Curr. Opin. Pediatr. 2010, 22, 219-225. 
23. Roy, A.; Kordas, K.; Lopez, P.; Rosado, J.L.; Cebrian, M.E.; Vargas, G.G.; Ronquillo, D.; Stoltzfus, R.J. Association between arsenic exposure and behavior among first-graders from Torreon, Mexico. Environ. Res. 2011, 111, 670-676.

24. Kimmel, C.B.; Ballard, W.W.; Kimmel, S.R.; Ullmann, B.; Schilling, T.F. Stages of embryonic development of the zebrafish. Dev. Dyn. 1995, 203, 253-310.

25. Blader, P.; Strähle, U. Zebrafish developmental genetics and central nervous system development. Hum. Mol. Genet. 2000, 9, 945-951.

26. Schmidt, R.; Strähle, U.; Scholpp, S. Neurogenesis in zebrafish-From embryo to adult. Neural Dev. 2013, doi: 10.1186/1749-8104-8-3.

27. Jeong, J.Y.; Kwon, H.B.; Ahn, J.C.; Kang, D.; Kwon, S.H.; Park, J.A.; Kim, K.W. Functional and developmental analysis of the blood-brain barrier in zebrafish. Brain Res. Bull. 2008, 75, 619-628.

28. Goldman, D.; Hankin, M.; Li, Z.; Dai, X.; Ding, J. Transgenic zebrafish for studying nervous system development and regeneration. Transgenic Res. 2001, 10, 21-33.

29. Umans, R.A.; Taylor, M.R. Zebrafish as a model to study drug transporters at the blood-brain barrier. Clin. Pharmacol. Ther. 2012, 92, 567-570.

30. Woo, K.; Fraser, S.E. Order and coherence in the fate map of the zebrafish nervous system. Development 1995, 121, 2595-2609.

31. Dawid, I.B. Developmental biology of zebrafish. Ann. N. Y. Acad. Sci. 2004, 1038, 88-93.

32. Halpern, M.E.; Thisse, C.; Ho, R.K.; Thisse, B.; Riggleman, B.; Trevarrow, B.; Weinberg, E.S.; Postlethwait, J.H.; Kimmel, C.B. Cell-autonomous shift from axial to paraxial mesodermal development in zebrafish floating head mutants. Development 1995, 4257-4264.

33. Hanneman, E.; Trevarrow, B.; Metcalfe, W.K.; Kimmel, C.B.; Westerfield, M. Segmental pattern of development of the hindbrain and spinal cord of the zebrafish embryo. Development 1988, 103, 49-58.

34. Vesterlund, L.; Jiao, H.; Unneberg, P.; Hovatta, O.; Kere, J. The zebrafish transcriptome during early development. BMC Dev. Biol. 2011, 11, doi:10.1186/1471-213X-11-30.

35. Weis, J.S. Analysis of the development of the nervous system of the zebrafish, Brachydanio rerio. II. The effect of nerve growth factor and its antiserum on the nervous system of the zebrafish. J. Embryol. Exp. Morphol. 1968, 19, 121-135.

36. Levin, E.D.; Sledge, D.; Roach, S.; Petro, A.; Donerly, S.; Linney, E. Persistent behavioral impairment caused by embryonic methylphenidate exposure in zebrafish. Neurotoxicol. Teratol. 2011, 33, 668-673.

37. Bretaud, S.; Lee, S.; Guo, S. Sensitivity of zebrafish to environmental toxins implicated in Parkinson's disease. Neurotoxicol. Teratol. 2004, 26, 857-864.

38. Carvan, M.J., 3rd; Loucks, E.; Weber, D.N.; Williams, F.E. Ethanol effects on the developing zebrafish: Neurobehavior and skeletal morphogenesis. Neurotoxicol. Teratol. 2004, 26, 757-768.

39. Chen, L.; Huang, C.; Hu, C.; Yu, K.; Yang, L.; Zhou, B. Acute exposure to DE-71: Effects on locomotor behavior and developmental neurotoxicity in zebrafish larvae. Environ. Toxicol. Chem. SETAC 2012, 31, 2338-2344. 
40. Chen, L.; Yu, K.; Huang, C.; Yu, L.; Zhu, B.; Lam, P.K.; Lam, J.C.; Zhou, B. Prenatal transfer of polybrominated diphenyl ethers (PBDEs) results in developmental neurotoxicity in zebrafish larvae. Environ. Sci. Technol. 2012, 46, 9727-9734.

41. Chen, X.; Huang, C.; Wang, X.; Chen, J.; Bai, C.; Chen, Y.; Chen, X.; Dong, Q.; Yang, D. BDE-47 disrupts axonal growth and motor behavior in developing zebrafish. Aquat. Toxicol. 2012, 120-121, 35-44.

42. Cowden, J.; Padnos, B.; Hunter, D.; MacPhail, R.; Jensen, K.; Padilla, S. Developmental exposure to valproate and ethanol alters locomotor activity and retino-tectal projection area in zebrafish embryos. Reprod. Toxicol. 2012, 33, 165-173.

43. Chen, Q.; Huang, N.N.; Huang, J.T.; Chen, S.; Fan, J.; Li, C.; Xie, F.K. Sodium benzoate exposure downregulates the expression of tyrosine hydroxylase and dopamine transporter in dopaminergic neurons in developing zebrafish. Birth Defects Res. B Dev. Reprod. Toxicol. 2009, 86, 85-91.

44. Chow, E.S.; Hui, M.N.; Lin, C.C.; Cheng, S.H. Cadmium inhibits neurogenesis in zebrafish embryonic brain development. Aquat. Toxicol. 2008, 87, 157-169.

45. DeMicco, A.; Cooper, K.R.; Richardson, J.R.; White, L.A. Developmental neurotoxicity of pyrethroid insecticides in zebrafish embryos. Toxicol. Sci. 2010, 113, 177-186.

46. Eddins, D.; Cerutti, D.; Williams, P.; Linney, E.; Levin, E.D. Zebrafish provide a sensitive model of persisting neurobehavioral effects of developmental chlorpyrifos exposure: Comparison with nicotine and pilocarpine effects and relationship to dopamine deficits. Neurotoxicol. Teratol. 2010, 32, 99-108.

47. Fan, C.Y.; Cowden, J.; Simmons, S.O.; Padilla, S.; Ramabhadran, R. Gene expression changes in developing zebrafish as potential markers for rapid developmental neurotoxicity screening. Neurotoxicol. Teratol. 2010, 32, 91-98.

48. Flentke, G.R.; Klingler, R.H.; Tanguay, R.L.; Carvan, M.J., 3rd; Smith, S.M. An evolutionarily conserved mechanism of calcium-dependent neurotoxicity in a zebrafish model of fetal alcohol spectrum disorders. Alcohol. Clin. Exp. Res. 2014, 38, 1255-1265.

49. Gu, A.; Shi, X.; Yuan, C.; Ji, G.; Zhou, Y.; Long, Y.; Song, L.; Wang, S.; Wang, X. Exposure to fenvalerate causes brain impairment during zebrafish development. Toxicol. Lett. 2010, 197, 188-192.

50. Hill, A.; Howard, C.V.; Strähle, U.; Cossins, A. Neurodevelopmental defects in zebrafish (Danio rerio) at environmentally relevant dioxin (TCDD) concentrations. Toxicol. Sci. 2003, 76, 392-399.

51. Loucks, E.; Carvan, M.J., 3rd. Strain-dependent effects of developmental ethanol exposure in zebrafish. Neurotoxicol. Teratol. 2004, 26, 745-755.

52. McClain, V.; Stapleton, H.M.; Tilton, F.; Gallagher, E.P. BDE 49 and developmental toxicity in zebrafish. Comp. Biochem. Physiol. Toxicol. Pharmacol. 2012, 155, 253-258.

53. Muth-Köhne, E.; Wichmann, A.; Delov, V.; Fenske, M. The classification of motor neuron defects in the zebrafish embryo toxicity test (ZFET) as an animal alternative approach to assess developmental neurotoxicity. Neurotoxicol. Teratol. 2012, 34, 413-424. 
54. Powers, C.M.; Slotkin, T.A.; Seidler, F.J.; Badireddy, A.R.; Padilla, S. Silver nanoparticles alter zebrafish development and larval behavior: Distinct roles for particle size, coating and composition. Neurotoxicol. Teratol. 2011, 33, 708-714.

55. Raftery, T.D.; Isales, G.M.; Yozzo, K.L.; Volz, D.C. High-content screening assay for identification of chemicals impacting spontaneous activity in zebrafish embryos. Environ. Sci. Technol. 2014, 48, 804-810.

56. Selderslaghs, I.W.; Hooyberghs, J.; Blust, R.; Witters, H.E. Assessment of the developmental neurotoxicity of compounds by measuring locomotor activity in zebrafish embryos and larvae. Neurotoxicol. Teratol. 2013, 37, 44-56.

57. Selderslaghs, I.W.; Hooyberghs, J.; de Coen, W.; Witters, H.E. Locomotor activity in zebrafish embryos: A new method to assess developmental neurotoxicity. Neurotoxicol. Teratol. 2010, 32, 460-471.

58. Shi, X.; Gu, A.; Ji, G.; Li, Y.; Di, J.; Jin, J.; Hu, F.; Long, Y.; Xia, Y.; Lu, C.; et al. Developmental toxicity of cypermethrin in embryo-larval stages of zebrafish. Chemosphere 2011, 85, 1010-1016.

59. Stehr, C.M.; Linbo, T.L.; Incardona, J.P.; Scholz, N.L. The developmental neurotoxicity of fipronil: Notochord degeneration and locomotor defects in zebrafish embryos and larvae. Toxicol. Sci. 2006, 92, 270-278.

60. Sun, Y.; Dong, Z.; Khodabakhsh, H.; Chatterjee, S.; Guo, S. Zebrafish chemical screening reveals the impairment of dopaminergic neuronal survival by cardiac glycosides. PLoS One 2012, 7, e35645.

61. Ton, C.; Lin, Y.; Willett, C. Zebrafish as a model for developmental neurotoxicity testing. Birth Defects Res. A Clin. Mol. Teratol. 2006, 76, 553-567.

62. Wen, L.; Wei, W.; Gu, W.; Huang, P.; Ren, X.; Zhang, Z.; Zhu, Z.; Lin, S.; Zhang, B. Visualization of monoaminergic neurons and neurotoxicity of MPTP in live transgenic zebrafish. Dev. Biol. 2008, 314, 84-92.

63. Xue, J.Y.; Li, X.; Sun, M.Z.; Wang, Y.P.; Wu, M.; Zhang, C.Y.; Wang, Y.N.; Liu, B.; Zhang, Y.S.; Zhao, X.; et al. An assessment of the impact of $\mathrm{SiO}_{2}$ nanoparticles of different sizes on the rest/wake behavior and the developmental profile of zebrafish larvae. Small 2013, 9, 3161-3168.

64. Yang, D.; Lauridsen, H.; Buels, K.; Chi, L.H.; la Du, J.; Bruun, D.A.; Olson, J.R.; Tanguay, R.L.; Lein, P.J. Chlorpyrifos-oxon disrupts zebrafish axonal growth and motor behavior. Toxicol. Sci. 2011, 121, 146-159.

65. Yen, J.; Donerly, S.; Levin, E.D.; Linney, E.A. Differential acetylcholinesterase inhibition of chlorpyrifos, diazinon and parathion in larval zebrafish. Neurotoxicol. Teratol. 2011, 33, 735-741.

66. Zellner, D.; Padnos, B.; Hunter, D.L.; MacPhail, R.C.; Padilla, S. Rearing conditions differentially affect the locomotor behavior of larval zebrafish, but not their response to valproate-induced developmental neurotoxicity. Neurotoxicol. Teratol. 2011, 33, 674-679.

67. Smith, L.E.; Carvan, M.J., 3rd; Dellinger, J.A.; Ghorai, J.K.; White, D.B.; Williams, F.E.; Weber, D.N. Developmental selenomethionine and methylmercury exposures affect zebrafish learning. Neurotoxicol. Teratol. 2010, 32, 246-255. 
68. Weber, D.N.; Connaughton, V.P.; Dellinger, J.A.; Klemer, D.; Udvadia, A.; Carvan, M.J., 3rd. Selenomethionine reduces visual deficits due to developmental methylmercury exposures. Physiol. Behav. 2008, 93, 250-260.

69. Wirbisky, S.E.; Weber, G.J.; Lee, J.W.; Cannon, J.R.; Freeman, J.L. Novel dose-dependent alterations in excitatory GABA during embryonic development associated with lead $(\mathrm{Pb})$ neurotoxicity. Toxicol. Lett. 2014, 229, 1-8.

70. Zhang, J.; Peterson, S.M.; Weber, G.J.; Zhu, X.; Zheng, W.; Freeman, J.L. Decreased axonal density and altered expression profiles of axonal guidance genes underlying lead $(\mathrm{Pb})$ neurodevelopmental toxicity at early embryonic stages in the zebrafish. Neurotoxicol. Teratol. 2011, 33, 715-320.

71. Howe, K.; Clark, M.D.; Torroja, C.F.; Torrance, J.; Berthelot, C.; Muffato, M.; Collins, J.E.; Humphray, S.; McLaren, K.; Matthews, L.; et al. The zebrafish reference genome sequence and its relationship to the human genome. Nature 2013, 496, 498-503.

72. Papan, C.; Campos-Ortega, J.A. Region-specific cell clones in the developing spinal cord of the zebrafish. Dev. Genes Evol. 1999, 209, 135-144.

73. Papan, C.; Campos-Ortega, J.A. On the formation of the neural keel and neural tube in the zebrafishDanio (Brachydanio) rerio. Roux's Arch. Dev. Biol. 1994, 203, 178-186.

74. Kimmel, C.B. Patterning the brain of the zebrafish embryo. Annu. Rev. Neurosci. 1993, 16, 707-732.

75. Ross, L.S.; Parrett, T.; Easter, S.S., Jr. Axonogenesis and morphogenesis in the embryonic zebrafish brain. J. Neurosci. 1992, 12, 467-482.

76. Wilson, S.W.; Ross, L.S.; Parrett, T.; Easter, S.S., Jr. The development of a simple scaffold of axon tracts in the brain of the embryonic zebrafish, Brachydanio rerio. Development 1990, 108, 121-145.

77. Myers, P.Z.; Eisen, J.S.; Westerfield, M. Development and axonal outgrowth of identified motoneurons in the zebrafish. J. Neurosci. 1986, 6, 2278-2289.

78. Pike, S.H.; Melancon, E.F.; Eisen, J.S. Pathfinding by zebrafish motoneurons in the absence of normal pioneer axons. Development 1992, 114, 825-831.

79. Abbott, N.J.; Patabendige, A.A.; Dolman, D.E.; Yusof, S.R.; Begley, D.J. Structure and function of the blood-brain barrier. Neurobiol. Dis. 2010, 37, 13-25.

80. Abbott, N.J.; Ronnback, L.; Hansson, E. Astrocyte-endothelial interactions at the blood-brain barrier. Nat. Rev. Neurosci. 2006, 7, 41-53.

81. Bernacki, J.; Dobrowolska, A.; Nierwinska, K.; Malecki, A. Physiology and pharmacological role of the blood-brain barrier. Pharmacol. Rep. 2008, 60, 600-622.

82. Lawther, B.K.; Sajith, K.; Hari, K. Blood-brain barrier. Contin. Educ. Anaesth. Crit. Care Pain 2011, 11, 128-132.

83. Banks, W.A. Characteristics of compounds that cross the blood-brain barrier. BMC Neurol. 2009, doi: 10.1186/1471-2377-9-S1-S3.

84. Oldendorf, W.H. Lipid solubility and drug penetration of the blood brain barrier. Proc. Soc. Exp. Biol. Med. 1974, 147, 813-815.

85. Adinolfi, M. The development of the human blood-CSF-brain barrier. Dev. Med. Child Neurol. 1985, 27, 532-537. 
86. Johnson, M.H. Functional brain development in humans. Nat. Rev. Neurosci. 2001, 2, 475-483.

87. Rodier, P.M. Developing brain as a target of toxicity. Environ. Health Perspect. 1995, 103 (Suppl. 6), 73-76.

88. Ek, C.J.; Dziegielewska, K.M.; Habgood, M.D.; Saunders, N.R. Barriers in the developing brain and neurotoxicology. Neurotoxicology 2012, 33, 586-604.

89. Luissint, A.C.; Artus, C.; Glacial, F.; Ganeshamoorthy, K.; Couraud, P.O. Tight junctions at the blood brain barrier: Physiological architecture and disease-associated dysregulation. Fluids Barriers CNS 2012, 9, 23.

90. Tam, S.J.; Watts, R.J. Connecting vascular and nervous system development: Angiogenesis and the blood-brain barrier. Annu. Rev. Neurosci. 2010, 33, 379-408.

91. Hawkins, B.T.; Davis, T.P. The blood-brain barrier/neurovascular unit in health and disease. Pharmacol. Rev. 2005, 57, 173-185.

92. Morita, K.; Sasaki, H.; Furuse, M.; Tsukita, S. Endothelial claudin: Claudin-5/TMVCF constitutes tight junction strands in endothelial cells. J. Cell Biol. 1999, 147, 185-194.

93. Nitta, T.; Hata, M.; Gotoh, S.; Seo, Y.; Sasaki, H.; Hashimoto, N.; Furuse, M.; Tsukita, S. Size-selective loosening of the blood-brain barrier in claudin-5-deficient mice. J. Cell Biol. 2003, $161,653-660$.

94. Fanning, A.S.; Jameson, B.J.; Jesaitis, L.A.; Anderson, J.M. The tight junction protein ZO-1 establishes a link between the transmembrane protein occludin and the actin cytoskeleton. J. Biol. Chem. 1998, 273, 29745-29753.

95. Furuse, M.; Itoh, M.; Hirase, T.; Nagafuchi, A.; Yonemura, S.; Tsukita, S.; Tsukita, S. Direct association of occludin with ZO-1 and its possible involvement in the localization of occludin at tight junctions. J. Cell Biol. 1994, 127, 1617-1626.

96. Stevenson, B.R.; Siliciano, J.D.; Mooseker, M.S.; Goodenough, D.A. Identification of ZO-1: A high molecular weight polypeptide associated with the tight junction (zonula occludens) in a variety of epithelia. J. Cell Biol. 1986, 103, 755-766.

97. Abdelilah-Seyfried, S. Claudin-5a in developing zebrafish brain barriers: Another brick in the wall. Bioessays 2010, 32, 768-776.

98. Kiener, T.K.; Sleptsova-Friedrich, I.; Hunziker, W. Identification, tissue distribution and developmental expression of tjp1/zo-1, tjp2/zo-2 and tjp3/zo-3 in the zebrafish, Danio rerio. Gene Expr. Patterns 2007, 7, 767-776.

99. Xie, J.; Farage, E.; Sugimoto, M.; Anand-Apte, B. A novel transgenic zebrafish model for blood-brain and blood-retinal barrier development. BMC Dev. Biol. 2010, 10, 76.

100. ZFIN Staff. Curation of Orthology Data. Manually Curated Data. 2003. Available online: http://zfin.org/ (accessed on 1 April 2014).

101. Zhang, J.; Piontek, J.; Wolburg, H.; Piehl, C.; Liss, M.; Otten, C.; Christ, A.; Willnow, T.E.; Blasig, I.E.; Abdelilah-Seyfried, S. Establishment of a neuroepithelial barrier by Claudin5a is essential for zebrafish brain ventricular lumen expansion. Proc. Natl. Acad. Sci. USA 2010, 107, $1425-1430$.

102. Fleming, A.; Diekmann, H.; Goldsmith, P. Functional characterisation of the maturation of the blood-brain barrier in larval zebrafish. PLoS One 2013, 8, e77548. 
103. Hughes, M.F.; Beck, B.D.; Chen, Y.; Lewis, A.S.; Thomas, D.J. Arsenic exposure and toxicology: A historical perspective. Toxicol. Sci. 2011, 123, 305-332.

104. Sun, G. Arsenic contamination and arsenicosis in China. Toxicol. Appl. Pharmacol. 2004, 198, 268-271.

105. Wang, S.; Mulligan, C.N. Occurrence of arsenic contamination in Canada: Sources, behavior and distribution. Sci. Total Environ. 2006, 366, 701-721.

106. Rodriguez-Lado, L.; Sun, G.; Berg, M.; Zhang, Q.; Xue, H.; Zheng, Q.; Johnson, C.A. Groundwater arsenic contamination throughout China. Science 2013, 341, 866-868.

107. Nordstrom, D.K. Worldwide occurrences of arsenic in ground water. Science 2002, 296, 2143-2145.

108. Balazs, C.L.; Morello-Frosch, R.; Hubbard, A.E.; Ray, I. Environmental justice implications of arsenic contamination in California's San Joaquin Valley: A cross-sectional, cluster-design examining exposure and compliance in community drinking water systems. Environ. Health 2012, 11, 84 .

109. Nahar, M.N.; Inaoka, T.; Fujimura, M. A consecutive study on arsenic exposure and intelligence quotient (IQ) of children in Bangladesh. Environ. Health Prev. Med. 2014, 19, 194-199.

110. Rosado, J.L.; Ronquillo, D.; Kordas, K.; Rojas, O.; Alatorre, J.; Lopez, P.; Garcia-Vargas, G.; del Carmen Caamano, M.; Cebrian, M.E.; Stoltzfus, R.J. Arsenic exposure and cognitive performance in Mexican schoolchildren. Environ. Health Perspect. 2007, 115, 1371-1375.

111. Wang, S.X.; Wang, Z.H.; Cheng, X.T.; Li, J.; Sang, Z.P.; Zhang, X.D.; Han, L.L.; Qiao, X.Y.; Wu, Z.M.; Wang, Z.Q. Arsenic and fluoride exposure in drinking water: Children's IQ and growth in Shanyin county, Shanxi province, China. Environ. Health Perspect. 2007, 115, 643-647.

112. Wasserman, G.A.; Liu, X.; Loiacono, N.J.; Kline, J.; Factor-Litvak, P.; van Geen, A.; Mey, J.L.; Levy, D.; Abramson, R.; Schwartz, A.; et al. A cross-sectional study of well water arsenic and child IQ in Maine schoolchildren. Environ. Health 2014, 13, 23.

113. Hamadani, J.D.; Tofail, F.; Nermell, B.; Gardner, R.; Shiraji, S.; Bottai, M.; Arifeen, S.E.; Huda, S.N.; Vahter, M. Critical windows of exposure for arsenic-associated impairment of cognitive function in pre-school girls and boys: A population-based cohort study. Int. J. Epidemiol. 2011, 40, 1593-1604.

114. Parajuli, R.P.; Fujiwara, T.; Umezaki, M.; Furusawa, H.; Watanabe, C. Home environment and prenatal exposure to lead, arsenic and zinc on the neurodevelopment of six-month-old infants living in Chitwan Valley, Nepal. Neurotoxicol. Teratol. 2014, 41, 89-95.

115. Parajuli, R.P.; Fujiwara, T.; Umezaki, M.; Watanabe, C. Association of cord blood levels of lead, arsenic, and zinc with neurodevelopmental indicators in newborns: A birth cohort study in Chitwan Valley, Nepal. Environ. Res. 2013, 121, 45-51.

116. Luo, J.; Qiu, Z.; Chen, J.; Zhang, L.; Liu, W.; Tan, Y.; Shu, W. Maternal and early life arsenite exposure impairs neurodevelopment and increases the expression of PSA-NCAM in hippocampus of rat offspring. Toxicology 2013, 311, 99-106.

117. Rodriguez, V.M.; Carrizales, L.; Mendoza, M.S.; Fajardo, O.R.; Giordano, M. Effects of sodium arsenite exposure on development and behavior in the rat. Neurotoxicol. Teratol. 2002, 24, $743-750$. 
118. Xi, S.; Sun, W.; Wang, F.; Jin, Y.; Sun, G. Transplacental and early life exposure to inorganic arsenic affected development and behavior in offspring rats. Arch. Toxicol. 2009, 83, 549-556.

119. Sannadi, S.; Kadeyala, P.K.; Gottipolu, R.R. Reversal effect of monoisoamyl dimercaptosuccinic acid (MiADMSA) for arsenic and lead induced perturbations in apoptosis and antioxidant enzymes in developing rat brain. Int. J. Dev. Neurosci. 2013, 31, 586-597.

120. Li, D.; Lu, C.; Wang, J.; Hu, W.; Cao, Z.; Sun, D.; Xia, H.; Ma, X. Developmental mechanisms of arsenite toxicity in zebrafish (Danio rerio) embryos. Aquat. Toxicol. 2009, 91, 229-237.

121. Radonjic, M.; Cappaert, N.L.; de Vries, E.F.; de Esch, C.E.; Kuper, F.C.; van Waarde, A.; Dierckx, R.A.; Wadman, W.J.; Wolterbeek, A.P.; Stierum, R.H.; et al. Delay and impairment in brain development and function in rat offspring after maternal exposure to methylmercury. Toxicol. Sci. 2013, 133, 112-124.

122. Jayashankar, S.; Glover, C.N.; Folven, K.I.; Brattelid, T.; Hogstrand, C.; Lundebye, A.K. Cerebral gene expression and neurobehavioural responses in mice pups exposed to methylmercury and docosahexaenoic acid through the maternal diet. Environ. Toxicol. Pharmacol. 2012, 33, 26-38.

123. Jayashankar, S.; Glover, C.N.; Folven, K.I.; Brattelid, T.; Hogstrand, C.; Lundebye, A.K. Cerebral gene expression in response to single or combined gestational exposure to methylmercury and selenium through the maternal diet. Cell Biol. Toxicol. 2011, 27, 181-197.

124. Glover, C.N.; Zheng, D.; Jayashankar, S.; Sales, G.D.; Hogstrand, C.; Lundebye, A.K. Methylmercury speciation influences brain gene expression and behavior in gestationally-exposed mice pups. Toxicol. Sci. 2009, 110, 389-400.

125. Ho, N.Y.; Yang, L.; Legradi, J.; Armant, O.; Takamiya, M.; Rastegar, S.; Strähle, U. Gene responses in the central nervous system of zebrafish embryos exposed to the neurotoxicant methyl mercury. Environ. Sci. Technol. 2013, 47, 3316-3325.

126. Cauli, O.; Piedrafita, B.; Llansola, M.; Felipo, V. Gender differential effects of developmental exposure to methyl-mercury, polychlorinated biphenyls 126 or 153 , or its combinations on motor activity and coordination. Toxicology 2013, 311, 61-68.

127. Kasten-Jolly, J.; Heo, Y.; Lawrence, D.A. Central nervous system cytokine gene expression: Modulation by lead. J. Biochem. Mol. Toxicol. 2011, 25, 41-54.

128. Peterson, S.M.; Zhang, J.; Weber, G.; Freeman, J.L. Global gene expression analysis reveals dynamic and developmental stage-dependent enrichment of lead-induced neurological gene alterations. Environ. Health Perspect. 2011, 119, 615-621.

129. Luo, M.; Xu, Y.; Cai, R.; Tang, Y.; Ge, M.M.; Liu, Z.H.; Xu, L.; Hu, F.; Ruan, D.Y.; Wang, H.L. Epigenetic histone modification regulates developmental lead exposure induced hyperactivity in rats. Toxicol. Lett. 2014, 225, 78-85.

130. Molina, R.M.; Phattanarudee, S.; Kim, J.; Thompson, K.; Wessling-Resnick, M.; Maher, T.J.; Brain, J.D. Ingestion of $\mathrm{Mn}$ and $\mathrm{Pb}$ by rats during and after pregnancy alters iron metabolism and behavior in offspring. Neurotoxicology 2011, 32, 413-422.

131. Rice, C.; Ghorai, J.K.; Zalewski, K.; Weber, D.N. Developmental lead exposure causes startle response deficits in zebrafish. Aquat. Toxicol. 2011, 105, 600-608. 
132. Chen, J.; Chen, Y.; Liu, W.; Bai, C.; Liu, X.; Liu, K.; Li, R.; Zhu, J.H.; Huang, C. Developmental lead acetate exposure induces embryonic toxicity and memory deficit in adult zebrafish. Neurotoxicol. Teratol. 2012, 34, 581-586.

133. Dou, C.; Zhang, J. Effects of lead on neurogenesis during zebrafish embryonic brain development. J. Hazard. Mater. 2011, 194, 277-282.

134. Pacyna, E.G.; Pacyna, J.M.; Sundseth, K.; Munthe, J.; Kindbom, K.; Wilson, S.; Steenhuisen, F.; Maxson, P. Global emission of mercury to the atmosphere from anthropogenic sources in 2005 and projections to 2020. Atmos. Environ. 2010, 44, 2487-2499.

135. Sheehan, M.C.; Burke, T.A.; Navas-Acien, A.; Breysse, P.N.; McGready, J.; Fox, M.A. Global methylmercury exposure from seafood consumption and risk of developmental neurotoxicity: A systematic review. Bull. World Health Organ. 2014, 92, 254F-269F.

136. Wiener, J.G.; Suchanek, T.H. The basis for ecotoxicological concern in aquatic ecosystems contaminated by historical mercury mining. Ecol. Appl. 2008, 18 (8 Suppl.), A3-A11.

137. Ekino, S.; Susa, M.; Ninomiya, T.; Imamura, K.; Kitamura, T. Minamata disease revisited: An update on the acute and chronic manifestations of methyl mercury poisoning. J. Neurol. Sci. 2007, 262, 131-144.

138. Harada, M. Minamata disease: Methylmercury poisoning in Japan caused by environmental pollution. Crit. Rev. Toxicol. 1995, 25, 1-24.

139. Shamlaye, C.; Davidson, P.W.; Myers, G.J. The Seychelles child development study: Two decades of collaboration. Seychelles Med. Dent. J. 2004, 7, 92-98.

140. Davidson, P.W.; Cory-Slechta, D.A.; Thurston, S.W.; Huang, L.S.; Shamlaye, C.F.; Gunzler, D.; Watson, G.; van Wijngaarden, E.; Zareba, G.; Klein, J.D.; et al. Fish consumption and prenatal methylmercury exposure: Cognitive and behavioral outcomes in the main cohort at 17 years from the Seychelles child development study. Neurotoxicology 2011, 32, 711-717.

141. Davidson, P.W.; Myers, G.J.; Cox, C.; Axtell, C.; Shamlaye, C.; Sloane-Reeves, J.; Cernichiari, E.; Needham, L.; Choi, A.; Wang, Y.; et al. Effects of prenatal and postnatal methylmercury exposure from fish consumption on neurodevelopment: Outcomes at 66 months of age in the Seychelles Child Development Study. JAMA 1998, 280, 701-707.

142. Myers, G.J.; Davidson, P.W.; Cox, C.; Shamlaye, C.F.; Choisy, O.; Cernichiari, E.; Choi, A.; Sloane-Reeves, J.; Axtell, C.; Gao, P.; et al. The Seychelles child development study: Results and new directions through twenty-nine months. Water Air Soil Pollut. 1997, 97, 53-61.

143. Myers, G.J.; Davidson, P.W.; Cox, C.; Shamlaye, C.F.; Palumbo, D.; Cernichiari, E.; Sloane-Reeves, J.; Wilding, G.E.; Kost, J.; Huang, L.S.; et al. Prenatal methylmercury exposure from ocean fish consumption in the Seychelles child development study. Lancet 2003, 361, 1686-1692.

144. Debes, F.; Budtz-Jorgensen, E.; Weihe, P.; White, R.F.; Grandjean, P. Impact of prenatal methylmercury exposure on neurobehavioral function at age 14 years. Neurotoxicol. Teratol. 2006, 28, 536-547.

145. Grandjean, P.; Weihe, P.; White, R.F.; Debes, F.; Araki, S.; Yokoyama, K.; Murata, K.; Sorensen, N.; Dahl, R.; Jorgensen, P.J. Cognitive deficit in 7-year-old children with prenatal exposure to methylmercury. Neurotoxicol. Teratol. 1997, 19, 417-428. 
146. Grandjean, P.; White, R.F.; Weihe, P.; Jorgensen, P.J. Neurotoxic risk caused by stable and variable exposure to methylmercury from seafood. Ambul. Pediatr. 2003, 3, 18-23.

147. Murata, K.; Weihe, P.; Budtz-Jorgensen, E.; Jorgensen, P.J.; Grandjean, P. Delayed brainstem auditory evoked potential latencies in 14-year-old children exposed to methylmercury. J. Pediatr. 2004, 144, 177-183.

148. Saint-Amour, D.; Roy, M.S.; Bastien, C.; Ayotte, P.; Dewailly, E.; Despres, C.; Gingras, S.; Muckle, G. Alterations of visual evoked potentials in preschool Inuit children exposed to methylmercury and polychlorinated biphenyls from a marine diet. Neurotoxicology 2006, 27, $567-578$.

149. Julvez, J.; Debes, F.; Weihe, P.; Choi, A.; Grandjean, P. Sensitivity of continuous performance test (CPT) at age 14 years to developmental methylmercury exposure. Neurotoxicol. Teratol. 2010, 32, 627-632.

150. Rice, D.C. Effects of developmental methylmercury exposure on nervous system function in monkeys. In Methylmercury and Neurotoxicity; Ceccatelli, S., Aschner, M., Eds.; Springer Science + Busniess Media, LLC: New York, NY, USA, 2012; Chapter 8, pp. 143-161.

151. Gunderson, V.M.; Grant, K.S.; Burbacher, T.M.; Fagan, J.F., 3rd; Mottet, N.K. The effect of low-level prenatal methylmercury exposure on visual recognition memory in infant crab-eating macaques. Child Dev. 1986, 57, 1076-1083.

152. Gunderson, V.M.; Grant-Webster, K.S.; Burbacher, T.M.; Mottet, N.K. Visual recognition memory deficits in methylmercury-exposed Macaca fascicularis infants. Neurotoxicol. Teratol. 1988, 10, 373-379.

153. Burbacher, T.M.; Sackett, G.P.; Mottet, N.K. Methylmercury effects on the social behavior of Macaca fascicularis infants. Neurotoxicol. Teratol. 1990, 12, 65-71.

154. Rice, D.C.; Gilbert, S.G. Early chronic low-level methylmercury poisoning in monkeys impairs spatial vision. Science 1982, 216, 759-761.

155. Rice, D.C.; Gilbert, S.G. Effects of developmental exposure to methyl mercury on spatial and temporal visual function in monkeys. Toxicol. Appl. Pharmacol. 1990, 102, 151-163.

156. Newland, M.C.; Hoffman, D.J.; Heath, J.C.; Donlin, W.D. Response inhibition is impaired by developmental methylmercury exposure: Acquisition of low-rate lever-pressing. Behav. Brain Res. 2013, 253, 196-205.

157. Beyrouty, P.; Stamler, C.J.; Liu, J.N.; Loua, K.M.; Kubow, S.; Chan, H.M. Effects of prenatal methylmercury exposure on brain monoamine oxidase activity and neurobehaviour of rats. Neurotoxicol. Teratol. 2006, 28, 251-259.

158. Bjorklund, O.; Kahlstrom, J.; Salmi, P.; Ogren, S.O.; Vahter, M.; Chen, J.F.; Fredholm, B.B.; Dare, E. The effects of methylmercury on motor activity are sex- and age-dependent, and modulated by genetic deletion of adenosine receptors and caffeine administration. Toxicology 2007, 241, 119-133.

159. Miyamoto, K.; Nakanishi, H.; Moriguchi, S.; Fukuyama, N.; Eto, K.; Wakamiya, J.; Murao, K.; Arimura, K.; Osame, M. Involvement of enhanced sensitivity of $N$-methyl-D-aspartate receptors in vulnerability of developing cortical neurons to methylmercury neurotoxicity. Brain Res. 2001, $901,252-258$. 
160. Onishchenko, N.; Tamm, C.; Vahter, M.; Hokfelt, T.; Johnson, J.A.; Johnson, D.A.; Ceccatelli, S. Developmental exposure to methylmercury alters learning and induces depression-like behavior in male mice. Toxicol. Sci. 2007, 97, 428-437.

161. Roegge, C.S.; Morris, J.R.; Villareal, S.; Wang, V.C.; Powers, B.E.; Klintsova, A.Y.; Greenough, W.T.; Pessah, I.N.; Schantz, S.L. Purkinje cell and cerebellar effects following developmental exposure to PCBs and/or MeHg. Neurotoxicol. Teratol. 2006, 28, 74-85.

162. Bertossi, M.; Girolamo, F.; Errede, M.; Virgintino, D.; Elia, G.; Ambrosi, L.; Roncali, L. Effects of methylmercury on the microvasculature of the developing brain. Neurotoxicology 2004, 25, 849-857.

163. Coccini, T.; Roda, E.; Castoldi, A.F.; Poli, D.; Goldoni, M.; Vettori, M.V.; Mutti, A.; Manzo, L. Developmental exposure to methylmercury and 2,2',4,4',5,5'-hexachlorobiphenyl (PCB153) affects cerebral dopamine D1-like and D2-like receptors of weanling and pubertal rats. Arch. Toxicol. 2011, 85, 1281-1294.

164. Roda, E.; Coccini, T.; Acerbi, D.; Castoldi, A.; Bernocchi, G.; Manzo, L. Cerebellum cholinergic muscarinic receptor (subtype-2 and -3) and cytoarchitecture after developmental exposure to methylmercury: An immunohistochemical study in rat. J. Chem. Neuroanat. 2008, 35, 285-294.

165. Stringari, J.; Nunes, A.K.; Franco, J.L.; Bohrer, D.; Garcia, S.C.; Dafre, A.L.; Milatovic, D.; Souza, D.O.; Rocha, J.B.; Aschner, M.; et al. Prenatal methylmercury exposure hampers glutathione antioxidant system ontogenesis and causes long-lasting oxidative stress in the mouse brain. Toxicol. Appl. Pharmacol. 2008, 227, 147-154.

166. Perino, J.; Ernhart, C.B. The relation of subclinical lead level to cognitive and sensorimotor impairment in black preschoolers. J. Learn. Disabil. 1974, 7, 616-620.

167. De la Burdé, B.; Choate, M.S. Early asymptomatic lead exposure and development at school age. J. Pediatr. 1975, 87, 638-642.

168. Bellinger, D.; Leviton, A.; Waternaux, C.; Needleman, H.; Rabinowitz, M. Longitudinal analyses of prenatal and postnatal lead exposure and early cognitive development. N. Engl. J. Med. 1987, 316, 1037-1043.

169. Dietrich, K.N.; Krafft, K.M.; Bornschein, R.L.; Hammond, P.B.; Berger, O.; Succop, P.A.; Bier, M. Low-level fetal lead exposure effect on neurobehavioral development in early infancy. Pediatrics 1987, 80, 721-730.

170. Liu, J.; Gao, D.; Chen, Y.; Jing, J.; Hu, Q.; Chen, Y. Lead exposure at each stage of pregnancy and neurobehavioral development of neonates. Neurotoxicology 2014, 44C, 1-7.

171. Surkan, P.J.; Zhang, A.; Trachtenberg, F.; Daniel, D.B.; McKinlay, S.; Bellinger, D.C. Neuropsychological function in children with blood lead levels $<10$ microg/dL. Neurotoxicology 2007, 28, 1170-1177.

172. Bushnell, P.J.; Bowman, R.E. Persistence of impaired reversal learning in young monkeys exposed to low levels of dietary lead. J. Toxicol. Environ. Health 1979, 5, 1015-1023.

173. Bushnell, P.J.; Bowman, R.E. Reversal learning deficits in young monkeys exposed to lead. Pharmacol. Biochem. Behav. 1979, 10, 733-742.

174. Levin, E.D.; Schneider, M.L.; Ferguson, S.A.; Schantz, S.L.; Bowman, R.E. Behavioral effects of developmental lead exposure in rhesus monkeys. Dev. Psychobiol. 1988, 21, 371-382. 
175. Rice, D.C. Behavioral effects of lead: Commonalities between experimental and epidemiologic data. Environ. Health Perspect. 1996, 104 (Suppl. 2), 337-351.

176. Laughlin, N.K.; Bushnell, P.J.; Bowman, R.E. Lead exposure and diet: Differential effects on social development in the rhesus monkey. Neurotoxicol. Teratol. 1991, 13, 429-440.

177. Devi, C.B.; Reddy, G.H.; Prasanthi, R.P.; Chetty, C.S.; Reddy, G.R. Developmental lead exposure alters mitochondrial monoamine oxidase and synaptosomal catecholamine levels in rat brain. Int. J. Dev. Neurosci. 2005, 23, 375-381.

178. Jett, D.A.; Beckles, R.A.; Navoa, R.V.; McLemore, G.L. Increased high-affinity nicotinic receptor-binding in rats exposed to lead during development. Neurotoxicol. Teratol. 2002, 24, 805-811.

179. Reddy, G.R.; Devi, B.C.; Chetty, C.S. Developmental lead neurotoxicity: Alterations in brain cholinergic system. Neurotoxicology 2007, 28, 402-407.

180. Wang, X.M.; Liu, W.J.; Zhang, R.; Zhou, Y.K. Effects of exposure to low-level lead on spatial learning and memory and the expression of mGluR1, NMDA receptor in different developmental stages of rats. Toxicol. Ind. Health 2013, 29, 686-696.

181. Petit, T.L.; LeBoutillier, J.C.; Brooks, W.J. Altered sensitivity to NMDA following developmental lead exposure in rats. Physiol. Behav. 1992, 52, 687-693.

182. Schneider, J.S.; Mettil, W.; Anderson, D.W. Differential effect of postnatal lead exposure on gene expression in the hippocampus and frontal cortex. J. Mol. Neurosci. 2012, 47, 76-88.

183. Xu, J.; Yan, H.C.; Yang, B.; Tong, L.S.; Zou, Y.X.; Tian, Y. Effects of lead exposure on hippocampal metabotropic glutamate receptor subtype 3 and 7 in developmental rats. J. Negat. Results Biomed. 2009, 8, 5.

184. Zito, K.; Scheuss, V. NMDA Receptor Function and Physiological Modulation. In Encyclopedia of Neuroscience; Squire, L.R., Ed.; Academic Press: Oxford, UK, 2009; Volume 6, pp. 1157-1164.

185. Kim, Y.; Ha, E.H.; Park, H.; Ha, M.; Kim, Y.; Hong, Y.C.; Kim, E.J.; Kim, B.N. Prenatal lead and cadmium co-exposure and infant neurodevelopment at 6 months of age: The mothers and children's environmental health (MOCEH) study. Neurotoxicology 2013, 35, 15-22.

186. Rai, A.; Maurya, S.K.; Khare, P.; Srivastava, A.; Bandyopadhyay, S. Characterization of developmental neurotoxicity of $\mathrm{As}, \mathrm{Cd}$, and $\mathrm{Pb}$ mixture: Synergistic action of metal mixture in glial and neuronal functions. Toxicol. Sci. 2010, 118, 586-601.

187. Wasserman, G.A.; Liu, X.; Parvez, F.; Factor-Litvak, P.; Ahsan, H.; Levy, D.; Kline, J.; van Geen, A.; Mey, J.; Slavkovich, V.; et al. Arsenic and manganese exposure and children's intellectual function. Neurotoxicology 2011, 32, 450-457.

188. Fischer, C.; Fredriksson, A.; Eriksson, P. Coexposure of neonatal mice to a flame retardant PBDE 99 (2,2',4,4',5-pentabromodiphenyl ether) and methyl mercury enhances developmental neurotoxic defects. Toxicol. Sci. 2008, 101, 275-285.

189. Vitalone, A.; Catalani, A.; Cinque, C.; Fattori, V.; Matteucci, P.; Zuena, A.R.; Costa, L.G. Long-term effects of developmental exposure to low doses of PCB 126 and methylmercury. Toxicol. Lett. 2010, 197, 38-45. 
190. Kalueff, A.V.; Gebhardt, M.; Stewart, A.M.; Cachat, J.M.; Brimmer, M.; Chawla, J.S.; Craddock, C.; Kyzar, E.J.; Roth, A.; Landsman, S.; et al. Towards a comprehensive catalog of zebrafish behavior 1.0 and beyond. Zebrafish 2013, 10, 70-86.

191. Li, X.; Ma, Y.; Li, D.; Gao, X.; Li, P.; Bai, N.; Luo, M.; Tan, X.; Lu, C.; Ma, X. Arsenic impairs embryo development via down-regulating Dvr1 expression in zebrafish. Toxicol. Lett. 2012, 212 , $161-168$.

192. Long, Y.; Li, Q.; Li, J.; Cui, Z. Molecular analysis, developmental function and heavy metal-induced expression of ABCC5 in zebrafish. Comp. Biochem. Physiol. Part B Biochem. Mol. Biol. 2011, 158, 46-55.

193. Hassan, S.A.; Moussa, E.A.; Abbott, L.C. The effect of methylmercury exposure on early central nervous system development in the zebrafish (Danio rerio) embryo. J. Appl. Toxicol. 2012, 32, 707-713.

194. Cuello, S.; Ximenez-Embun, P.; Ruppen, I.; Schonthaler, H.B.; Ashman, K.; Madrid, Y.; Luque-Garcia, J.L.; Camara, C. Analysis of protein expression in developmental toxicity induced by MeHg in zebrafish. Analyst 2012, 137, 5302-5311.

195. Lee, J.; Freeman, J.L. Zebrafish as a model for investigating developmental lead $(\mathrm{Pb})$ neurotoxicity as a risk factor in adult neurodegenerative disease: A mini-review. Neurotoxicology 2014, 43, 57-64.

196. Peterson, S.M.; Zhang, J.; Freeman, J.L. Developmental reelin expression and time point-specific alterations from lead exposure in zebrafish. Neurotoxicol. Teratol. 2013, 38, 53-60.

(C) 2014 by the authors; licensee MDPI, Basel, Switzerland. This article is an open access article distributed under the terms and conditions of the Creative Commons Attribution license (http://creativecommons.org/licenses/by/3.0/). 